\title{
Cash Savings from Net Equity Issues, Net Debt Issues, and Cash Flows International Evidence
}

\author{
Bruce Seifert \\ Department of Business Administration \\ College of Business and Public Administration \\ Old Dominion University \\ Norfolk, Va. 23529-0221 \\ phone: +1 (757) 683-3552 \\ fax: +1 (757) 683-5639 \\ e-mail: bseifert@odu.edu.
}

\section{Halit Gonenc}

Department of Economics, Econometrics and Finance

Faculty of Business and Economics University of Groningen

Nettelbosje 2, 9747 AE Groningen, NL phone: +31 (50) 3634237 fax: +31 (50) 3637356 e-mail: h.gonenc@rug.nl. 


\title{
Cash Savings from Net Equity Issues, Net Debt Issues, and Cash Flows International Evidence
}

\begin{abstract}
Our study examines cash savings from net equity issues, net debt issues and internally generated cash flows. Previous research has tended to focus on only one savings channel at a time and then report only an aggregate savings rate. We note first that savings rates depend on the level of cash flows. For negative cash flows, savings rates are very low from cash flows and higher from net equity and net debt issues. For higher levels of cash flows, savings rates from cash flows increase substantially while savings rates from net debt issues and net equity issues fall.

Using a sample of firms worldwide, we find that constrained firms have higher total savings rates than unconstrained companies which suggest that constrained firms which face costly external finance save more now in order to minimize the chance of not being able to fund valuable investment projects in the future. We also find that savings rates are positively related to investment opportunities, R\&D intensity, multinational status, and whether firms are located in countries with a bank-oriented system and negatively related to whether firms pay dividends and whether companies reside in common law countries. The relationships we observe are significant for the subset of firms that are constrained but are usually insignificant for unconstrained firms. Finally, our results suggest that when firms increase their savings, they usually use multiple channels as opposed to relying only on one channel.

Overall, our findings support the idea that firms save when they have important investments or activities (for example R\&D) in the future that need to be undertaken and save less when they appear to have sufficient resources to cover future contingencies. These results are consistent with a broad precautionary motive for saving.
\end{abstract}

EFM Classification Codes: 240, 230

Keywords: Cash savings, share issues, debt issues, cash flows, precautionary motives, international financial markets 


\section{Introduction}

This study examines cash savings from three main sources of cash; net equity issues, net debt issues, and internally generated cash flows. We examine the magnitude of these savings rates, the relationships among the rates, the effect of financial constraints on savings rates and some of the determinants of these rates. We use a large international data set covering the period 1991-2010.

Cash management has received a lot of attention in recent years. Part of the reason for this attention is the fact that cash and short-term investments represent a big part of a firm's balance sheet and the ratio of cash and short-term investments to total assets continues to get larger and larger. In our sample of firms for the period 1991-2010, the mean cash ratio (cash and short-term investments to lagged total assets) is 19.5 percent. Almost one fifth of all assets are tied up in cash or cash like assets. Perhaps more importantly, the cash ratio has steadily increased. In 1991 this ratio was 12.8 percent and by 2010 it had increased to 21.2 percent, a 66 percent increase. The change in cash (the difference in cash and short-term investments from one year to the next/total assets in the previous year) is 2.5 percent over the entire period. This fact emphasizes the steady increase in cash and cash like assets during this period. The recent literature attributes the increase in cash to an increase in precautionary motives (Bates et al., 2009, Duchin et al., 2010).

The problem with having a large amount of cash is that these assets earn a relatively small rate of return. In theory, investing in real assets should earn a much higher return. Also, in some cases, management may use the cash unwisely by spending it on unnecessary perks or worse still, expropriating it. (For the importance of corporate governance practices on cash management see 
Dittmar and Mahrt-Smith, 2007, Dittmar et al., 2003, Ferreira and Vilela, 2004, Harford et al., 2008, and Kusnadi and Wei, 2011.)

There has been a fair amount of literature devoted to understanding the determinants of cash holdings. Opler et al. (1999) and Dittmar et al. (2003) provide a detailed review of this literature. A more recent literature deals with a firm's desire to save cash. From a theoretical view, Riddick and Whited (2009) model optimal firm savings as a tradeoff between the cost of external finance and taxation of interest income ${ }^{1}$.

Empirically, a number of studies have examined cash savings from one particular channel. Khurana et al. (2006) observe that the sensitivity of cash to cash flows is greater for firms residing in less developed financial economies than from more developed economies. Almeida et al. (2004) report a positive sensitivity of cash from cash flows for constrained firms but an insignificant relationship from unconstrained firms. Kim and Weisbach (2008) examine the cash sensitivity to equity issues and find that firms on average save 49 (53.4) cents per dollar from IPO's (SEO's).

A few studies have examined cash savings from multiple sources. McLean (2011) studies savings rates from various sources. He reports mean yearly savings coefficients for US firms for the time period 1971-2008 for equity issues (.434), debt issues (.020), cash flows (.281), and other (.070). He shows that cash savings from equity issues has increased dramatically from 23 cents per dollar of equity issues in the 1970's to 60 cents per dollar during the period 1999 to 2008, a fact he attributes to increasing precautionary motives. None of the other sources of cash savings exhibit the same time trend as equity issues. McLean (2011) also observes that when equity issuance costs are low, firms save more cash. Gatchev et al. (2009) study changes in cash

\footnotetext{
${ }^{1}$ For a brief review of prior theoretical papers see Riddick and Whited (2009).
} 
holdings in a multi equation setting with changes in cash being one of their dependent variables. Their focus, however, is on firm investments.

Research on cash savings has generally focused on one channel at a time and assumed that the savings rates were constant across different cash flow levels. Researchers have modified their notion that the savings rates may be constant (see, for example, Gatchev et al., 2009) by noting that firms' investment behavior and financing patterns are different between a profit shortfall and a profit gain.

The purpose of our paper is twofold: First, we present some facts about the savings rates from net equity issues, net debt issues, and cash flows. We examine whether savings rates are constant across different cash flow levels (positive and negative and also different levels of positive cash flows). We inquire whether one savings rate (for example, savings from cash flows) affects another savings rate (for example, net debt issues). We believe that a major contribution of our paper is highlighting the relationship between savings rates from net equity, net debt, and cash flow as a function of the level of cash flows. Second, we examine a number of hypotheses concerning these savings rates. Some of these relationships have been studied extensively in the cash management literature (for example, the link between R\&D and cash levels) while others have not (the effect of multinationality on cash savings). We test if financially constrained firms save more than unconstrained firms. We ask whether good governance and good protection for suppliers of funds influence the savings rates. Furthermore, we explore the impact of a number of firm variables (R\&D, dividends, multinational status, and market-to-book ratios) and a country variable (whether a firm resides in a market or bank-based country) to see the effect of these variables on the savings rates. Our test of these variables is richer than previous studies because we look at the savings rates for the three channels (net equity issues, net debt issues and cash flow) together instead of just looking at only one of these channels. It is entirely possible that if a 
researcher is examining the effect of a variable on savings rates that if she only observes one channel, she could incorrectly conclude that the overall effect was positive. If instead she had examined all three channels together she might realize that the effect on one channel was positive but the effect on the other two channels was negative and the overall effect was negative. Examining the three channels simultaneously allows us to see whether cash savings from one channel are usually associated with increases in other channels or whether changes in one channel are largely independent of changes in the other channels. Thus a second major contribution of our paper is examining the decomposition of changes in savings.

Our main results can be summarized as follows. First, savings rates from net equity issues, net debt issues, and cash flows depend on the level of cash flows. For negative cash flows, savings rates are low from cash flows and higher from net equity and net debt issues. At higher levels of cash flows, savings rates increase from cash flows and decrease from net equity and debt issues. In fact, for the highest level of cash savings, savings from cash flows is at least twice the rate from either net equity issues or from net debt issues.

Second, savings rates are higher for financially constrained firms than for unconstrained firms. These results are consistent with the idea that financially constrained firms are plagued with costly external finance and/or unavailability of external funds and thus they save more now in order to minimize the chance of being unable to make profitable investments in the future. In addition, we do not find strong evidence that good or bad governance affects savings rates. We see that firms save more in countries that have lower protection for creditors and minority shareholders. We also observe that savings rates depend positively on investment opportunities, $\mathrm{R} \& \mathrm{D}$ ratios, and whether firms are multinational. We find evidence that dividends affect negatively savings ratios. We observe that the relationships between savings rates and key variables depend on whether firms are constrained or unconstrained. All of our relationships are 
much stronger for the sample of constrained variables than for the sample of unconstrained companies. Our results are in a strong accord with Almedia et al. (2004) who stress the importance of the distinction between constrained and unconstrained companies.

These results can be interpreted as evidence that firms increase their savings when they worry about whether they will have enough funds to cover future investments or essential activities (for example, R\&D) and decrease savings when they appear to have adequate resources to cover future contingencies as is the case for dividend paying firms. Our findings are consistent with a broad precautionary motive for saving.

Third, we observe that financial structure (market or bank-based structures) has an influence on savings rates with bank-based countries showing higher savings rates. We attribute this to smaller external markets for firms residing in bank-based markets. These firms save more because they want to make sure that they do not miss out on valuable investments in the future.

Finally, we see evidence that when firms increase cash savings they do so from multiple sources. Cash savings from equity issues are generally positively associated with cash savings from debt and from cash flow.

The rest of the paper proceeds as follows: in section 2, we develop hypotheses, in section 3, we discuss data sources and our empirical design, in section 4, we present our results, and finally, in section 5, conclusions are offered.

\section{Hypotheses}

Firms that expect to raise external capital easily in the future do not have to worry now about saving for the future. On the other hand, firms that think they will have difficulty in raising future capital must consider saving now and forgoing current profitable investments in order to fund future investment possibilities. This is the argument that Almeida et al. (2004) make and 
suggest therefore that the cash flow sensitivity of cash should be positive for constrained firms but be insignificant for unconstrained firms. We extend this argument to net issues and net debt. Constrained firms may try, for example, to issue more stock or more debt than they need now and then save the extra proceeds. We believe that constrained firms will have higher saving rates than unconstrained firms. Hypothesis 1 follows:

Hypothesis 1: Savings rates will be higher for constrained firms than for unconstrained firms

We next look at firm specific attributes that may influence savings rates. In this regard we examine $R \& D$ intensity, investment opportunities, and dividend payouts. Our general principle is that future activities that are critical to a particular firm like $R \& D$ must be continued and resources need to be saved now in order to insure that these activities will be done in the future. For many firms R\&D cannot be stopped and then restarted without the real possibility that the firm's leading scientists may seek employment elsewhere or that the firm will fall behind its leading competitors in the race for innovation. Hypothesis 2 follows:

Hypothesis 2: Firms conducting a lot of $R \& D$ will save more than firms conducting no $R \& D$.

Similarly firms with very good investment opportunities risk losing a lot of money if they do not undertake these opportunities. As a result, they will want to save additional money now in order to make sure that they can partake in these endeavors in the future. Hypothesis 3 follows: Hypothesis 3: Firms with good investment opportunities will have higher savings rates than firms with less investment opportunities.

We posit that dividend paying firms will save less than firms that do not pay dividends. Many dividend paying firms are well established and do not have the investment opportunities that many younger more aggressive firms have. Also dividend paying firms have another source of capital to use if they need to in the future, namely to reduce their current or future dividend. 
There are costs to reducing a dividend, so firms will prefer not to source additional capital this way. Hypothesis 4 follows:

Hypothesis 4: Non-dividend paying firms will have higher savings rates than dividend paying

firms.

We examine whether the market structure of countries has an impact on savings rates. In particular, we look at whether a firm resides in a market or a bank-based country. We find in our study that firms from bank-based countries issue in total less net equity and net debt and thus we argue that firms from these countries may worry that they may not have access to enough future capital $^{2}$ from these sources of funds. As a result, the savings rates for these firms will probably be higher because of the fear that future capital will not always be available ${ }^{3}$. Hypothesis 5 follows: Hypothesis 5: Firms from bank-based countries will have higher savings rates than firms from market-based countries.

We also look at the effect of investor and creditor protection on cash savings. In countries where protection is better (stronger), suppliers of capital should be more willing to lend and companies should, in general, believe that capital will be more accessible now and also in the future. This greater accessibility of capital should allow firms residing in countries with greater protection of creditors and investors to save less. Hypothesis 6 follows:

\footnotetext{
${ }^{2}$ A possible counter argument is that in bank-based countries, firms may have more access to bank debt and thus not need as much capital from net equity and debt issues. We do not have data on bank debt. However, we do have data on the ratio of total debt to total assets and we find the mean ratio for market based countries (.133) is a little higher than the mean ratio for bank-based countries (.119). The median ratios are, however, higher for bank-based countries than market-based ones (.080 vs. .069). We conclude that the ratio of total debt to total assets is roughly the same for both groups. Firms in bank-based countries may therefore have as much access to debt as firms in market-based countries but their access to new equity issues is clearly less.

${ }^{3}$ Mclean and Zhao (2011) present evidence that cash savings from share issuance is higher in countries where equity financing is easier, the opposite of our hypothesis. However, they find this relationship only holds for firms with high precautionary motives. High precautionary motives have been shown to increase cash savings.
} 
Hypothesis 6: Firms in residing in countries with less protection for creditors and investors will have higher savings rates than firms located in countries with greater protection for creditors and investors.

We also examine whether firms with poor governance save more or less than firms with good governance. Neither theory nor previous empirical studies provide a clear cut prediction as to whether well governed or poorly governed firms should save more.

By definition poorly governed firms make bad decisions. They can spend unwisely on investments, procure unnecessary perks for their managers and owners, fail to control costs, and save too much now in order to avoid the scrutiny of capital markets in the future. If firms that are poorly governed simply spend too much then it might be expected that poorly governed firms would have lower savings rates. On the other hand, if poorly governed firms pay little dividends or repurchase stock rarely and accumulate cash in order to spend unwisely in the future then poorly governed firms might have higher savings rates.

Empirically the relationship between governance and cash levels is not clear. Harford et al. (2008) find that poorly governed US firms have less cash reserves than well governed firms. These firms spend cash quickly on capital expenditures and acquisitions. Harford et al. point out that there can be negative reaction to firms having too much cash and firms may respond by acquiring assets. Dittmar and Mahrt-Smith (2007) also observe that poorly governed US firms get rid of cash quickly. On the other hand, Dittmar et al. (2003) find that firms located in countries with weak shareholder protection hold close to twice the amount of cash than firms do that reside in countries with high shareholder protection.

While the relationship between governance and savings is not clear cut, we expect well governed companies to save more since they are more profit oriented and should save when it is prudent to do so. 
Hypothesis 7: Well governed firms will save more than poorly governed firms

Finally, we examine the effect of multinationality on savings rates. In a recent paper, Pinkowitz et al. (2012) observe that US multinationals have increased abnormal cash holdings during the 2000's, a significant increase relative to foreign multinationals and other US firms. These authors are able to eliminate some hypotheses concerning why this increase has taken place but they do not provide a definite reason for the increase.

At first glance it might appear that multinationals might have lower savings rates. Like multidivisional firms, multinationals provide diversification benefits and thus could have lower cash levels than other firms. Duchin (2010) shows that multidivisional firms have significantly less cash than stand alone firms because they are diversified in their investment opportunities. A similar argument can be made for multinational firms. On the other hand, multinationals by definition are involved in so many areas (products and locations) and face so much uncertainty that they may need extra precautionary funds. We follow the lead of Pinkowitz et al. (2012) in the following hypothesis

Hypothesis 8: Multinational should have higher savings rates than domestic firms.

\section{Data Sources and Models}

We gather financial data from Worldscope from 1991 to 2010 for 72 countries. Following the usual practice, financial firms and utilities are eliminated due to the regulatory influence on these firms. We winsorize our data for two reasons. First, Worldscope makes occasional reporting errors and second, there are significant outliers in our data. As a result, the top and bottom 5 percent of the values for a particular variable are set equal to the 95 and 5 percent levels respectively for that variable. 


\subsection{Models}

Similar to McLean (2011) ${ }^{4}$ we initially estimate yearly cash savings from the following equation:

ChCash $_{i t}=a+b_{1}$ Net_Issue $_{i t}+b_{2}$ Net_Debt $_{i t}+b_{3}$ Cflow $_{i t}+b_{4}$ LnSize $_{i t}+e_{t}$

Hypotheses concerning the determinants of cash savings are tested with the following model:

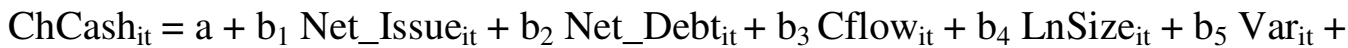

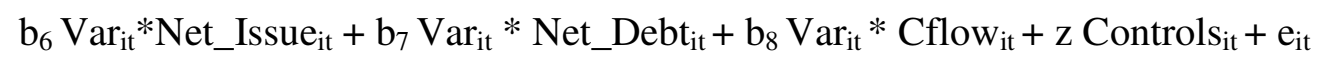

where ChCash ${ }^{5}$ is the change in cash and short-term investments from period $\mathrm{t}-1$ to $\mathrm{t}$ divided by total assets at time t-1, Net_Issue is the difference between new equity issues and redemptions at time $\mathrm{t}$ scaled by total assets at time t-1, Net_Debt is the difference between long-term borrowings and reductions in borrowing at time $\mathrm{t}$ scaled by total assets at time $\mathrm{t}-1$, Cflow is the cash flow for period t divided by total assets for period $\mathrm{t}-1, \mathrm{LnSize}$ is the natural logarithm of total assets in US dollars, Var is the variable of interest (financial constraint, R\&D, dividends, market-to-book, governance, multinational status, bank or market-based country, investor protection) for the particular hypothesis.

Controls are the controls used for the hypotheses and are ChStDebt and FD, where ChStDebt is the change in short-term debt (short-term debt and the current portion of long-term debt) from period t- 1 to period $\mathrm{t}$ scaled by total assets at time $\mathrm{t}-1$, and FD is an index of financial development composed of two components - a stock market development index and a financial intermediary index.

We use net equity issues and net debt issues instead of the corresponding gross issues because the firm gets to use only the net numbers, for example, to acquire investments or save

\footnotetext{
${ }^{4}$ Unlike McLean (2011) we do not estimate a coefficient for other sources of cash (for example, sales of property, plant, and equipment). Average amounts from this source are small.

${ }^{5}$ Exact definitions for each of the variables are given in Table 1.
} 
cash. If the firm issues 10 million dollars in debt and then redeems 3 million dollars in debt, it has only 7 million to use after the redemptions, not 10 million dollars. In those cases the firm is simply rolling over the debt (replacing old debt with new debt).

We use size in equations 1 and 2 to account for the possibility that there could be economies of scale in cash management. A country's financial development is included as a control in equation 2 due to Khurana et al. (2006) findings that cash savings from cash flows decrease with greater amounts of financial development. Finally, the change in short-term debt is added to equation 2 because as Almeida et al. (2004) point out that changes in short-term debt could affect cash savings in a couple of ways. Changes in short-term debt can be viewed as substitutes for cash or as the mechanism to build up cash.

We use OLS to estimate our equations over the period 1991-2010. Where appropriate, regression equations control for country, industry and year effects.

[Insert Table 1 about here]

\section{Results}

\subsection{Descriptive Statistics}

Table 2 (Panel A) provides descriptive statistics for firm year observations for (1) the entire sample, (2) US firms, (3) non-US firms, (4) firms from bank-based countries, and (5) firms from market-based countries. For many of the variables there are over 280,000 firm year observations. US firms account for 37 percent of all observations and firms from market-based countries represent 78 percent of the sample.

Our dependent variable is the yearly change in cash and short-term investments scaled by total assets in the previous year. The mean (median) change for the entire sample is $2.5(0.2)$ percent (Panel A). All four subsets (US, non-US, market-based, and bank-based) of the sample 
have mean changes of at least 1.9 percent, indicating that firms from around the world as well as from different economic regimes are generally increasing their percentage of cash and short-term investments. We also computed the cash ratio (cash and short-term investments in year to total assets in year t-1). In results not reported, we observe that the cash ratio increased from 12.8 percent in 1991 to 21.2 percent in 2010, an increase of 66 percent. Our finding that firms are increasing their cash and short-term investments mirror the conclusions of other researchers (McLean, 2011 and Bates et al., 2009).

Net equity issues (gross issues - redemptions) are positive for the entire sample with a mean (median) of $7.5(0.0)$ percent. From Panel A in Table 2, we find that means for net equity issues and gross equity issues are similar, implying that equity repurchases are not large in comparison to gross equity issues. Overall, it appears that many firms do not issue equity in a given year, but when they do, they make relatively large issues. Net equity issues were equal to zero 38 percent of the time (results not reported), implying that both gross issues and redemptions were zero for that particular observation ${ }^{6}$. Panel A in Table 2 also suggests that US firms issue relatively more equity than non-US firms and companies in market-based countries issue more equity than those in bank-based countries.

Panel A in Table 2 reveals a substantial difference between gross debt issues and net debt issues. The mean for net debt (1.6 percent) is only 22 percent of the mean for gross debt (7.4 percent) suggesting that the great majority of debt that is issued simply replaces existing debt. US firms issue more gross debt and have more net debt than non-US firms while market-based firms issue both more gross debt and have more net debt than firms in bank-based countries.

\footnotetext{
${ }^{6}$ It is, of course, possible that there were some firms that had equal positive amounts of gross equity issues and redemptions.
} 
Overall, firms in our sample have a slight positive cash flow. US firms and firms from market-based countries have a mean negative cash flow, while non-US firms and firms from bank-based countries have a positive cash flow. The data suggests that there are many US firms that have large negative cash flows as a percent of total assets, but the median US firm still has a positive cash flow.

The findings from Panel A in Table 2 indicate that in terms of mean numbers, the greatest source of new capital is net equity issues ( 7.5 percent) followed by net debt issues (1.6 percent) and lastly by cash flow ( 0.1 percent).

Panel B of Table 2 provides summary statistics by year for some of the key variables in our study. We start by examining the yearly variation of these variables. The change in cash and short-term investments is positive every year and varies between 0.5 percent (2001) and 4 percent (2004). Net equity issues are smallest in 1991 (3.2 percent) and peak in 2000 (12.1 percent). Likewise net debt issues are always positive and vary between 0.4 percent (2004) and 2.6 percent (1997, 1998, and 2007). Cash flows are positive from 1991-1998, peaking in 1994 (9.1 percent) and then turn negative from 1999 to 2009. Mean cash flows are lowest in 2001 (-4.5 percent).

Panel B shows that there clear trends in the data. Annual changes in cash and equity issues (both net and gross) have increased over time and the levels in 2010 are approximately twice those of 1991. Gross debt but not net debt has also increased over time.

The findings in Panel B also support our earlier conclusions that the difference between gross and net equity is small and that net debt is small relative to gross debt. For each of the 20 years, the difference between gross and net equity is equal to 0.5 percent or less. Also an inspection of the data shows that there are substantial differences between gross and net debt every year. 
In Panel C, we report the means and medians of the (1) change in cash, (2) gross and net equity issues, (3) gross and net debt issues, (4) cash flows, and (5) gross and net totals of the three sources of funds at different levels of cash flows. We look at negative cash flows, all positive cash flows, and the positive cash flows divided into three equal groups (low, medium, and high). Mean and median values of the change in cash flows are the highest for the high positive cash flow sample. Moving from negative to low positive cash flows to middle positive cash flows to high positive cash flows, the total amount of funds sourced (Net_Total) from net equity issues, net debt issues, and cash flows increases from -.121 to .07 to .137 to finally .292 . It seems reasonable to conjecture that firms might have lower savings rates from net equity and net debt issues in the high cash flow group because the total sources of funds is so much more. On the other hand, the savings rate from cash flow would be high if firms did not have sufficient spending uses for the additional inflows.

[Insert Table 2 about here]

\subsection{Coefficient Estimations for Cash Savings from Net Issues, Net Debt, and Cash Flow}

Tables 3-6 provide estimates of the coefficients for cash savings from net equity issues, net debt, and cash flow. We present the estimates for the entire period (1991-2010) in Table 3, yearly estimates (Table 4), country estimates (Table 5), and the effect of different levels of cash flows (positive versus negative and different levels of positive cash flows) on the estimates of the coefficients (Table 6).

Table 3 indicates that cash savings rates in the aggregate are positive for all three sources. Column 1 reports our estimates without controls and column 2 adds the two control variables. Column 1 (2) shows that over the entire period that the savings rate for net issues is .362 (.362), the savings rate for net debt is $.107(.101)$, and the savings rate for cash flows is $.116(.117)$. 
These results show that in the aggregate that the cash savings rate from net issues is approximately three times the rate from either net debt or cash flow.

Table 3 also examines the impact of the recent economic crisis on savings rates. We present estimates for each period separately (before the crisis in column 6 and during the crisis in column 5). We also create a dummy variable that equals 1 when the observation occurs between 2007 and 2010 and equals zero if the observation does not. We then interact the dummy with each of the sources of funds (net issues, net debt, and cash flow). These results are reported in columns 3 and 4. We perform an F-test to see if the sum of the coefficients on the interaction variables is significantly different from zero. The results of the F-tests suggest that savings rates in total did not change as a result of the economic crisis. In results not reported, we redid this analysis using different time periods (for example, just the years 2008-2009) to represent the economic crisis and the findings did not change.

[Insert Table 3 about here]

Table 4 presents yearly OLS estimates of cash savings from net equity issues, net debt issues and cash flow. The estimates are fairly stable. The coefficient for net issues varies between .293 (1993) and .396 (2003), for net debt the coefficient varies between .050 (1995) and .185 (2009), and for cash flow the range of estimates is .061 (1999) to .164 (2009).

[Insert Table 4 about here]

Table 5 gives coefficient estimates of savings rates from net equity issues, net debt issues, and cash flows by country (Panel A). In addition we present means for net equity issues, net debt issues, and cash flows (Panel B) and also the total average cash (as a percentage of lagged total assets) saved from each of the three channels (Panel C). The numbers in Panel C are the products 
of the numbers in Panel A and Panel B (for example, the coefficients from Panel A for new equity issues times the mean amount of net equity issues in Panel B).

Panel A shows that Columbia and Egypt have the highest savings rate from net equity issues (both over .600) while Mexico, Portugal and Zimbabwe have the lowest (all under .200) ${ }^{7}$. Japan has the highest savings rate from net debt issues (.331) while a few countries actually have a negative savings rate from net debt issues. Egypt and Kuwait have the highest savings rate from cash flows (over .400 ) while Bermuda is the only country with a negative savings rate from cash flows.

[Insert Table 5 about here]

\subsection{Cash Savings and the Levels of Cash Flows}

In this section, we examine the first main issue, namely whether the savings rates from net equity issues, net debt issues, and cash flows depend on the level of cash flows. It might be expected that the savings rate from cash flows for firms with negative cash flows would be small or negative. It is hard to save cash from cash flows when the cash flows are negative or very small. Savings from cash flows should become larger as the firm becomes more profitable. In addition, as the firm becomes more profitable savings rates from equity and debt issues could decrease as firms could save more from cash flows and thus depend less for savings from both equity and debt issues.

In Table 6 we examine whether savings rates are different between positive and negative cash flows (columns 1-3). We compare the savings coefficients when the cash flows are positive to when the cash flows are negative. We also create a dummy variable that equals one when cash

\footnotetext{
${ }^{7}$ Conclusions from the table should be viewed cautiously as the number of observations for some countries is small.
} 
flows are positive and zero otherwise. The dummy variable is then interacted with net equity issues, net debt issues, and cash flows.

Our findings from columns 1-3 in Table 6 indicate that the savings rate increases dramatically from cash flows as the firm goes from negative cash flows to positive cash flows. In addition, the savings rates decrease significantly for net debt issues and for net equity issues. Using the results from column 1, when cash flows are negative, firms save .046 dollars per dollar from cash flows but this increases to .351 dollars when cash flows are positive, an increase of .305. The savings rate drops from net equity issues (net debt issues) by .048 (.146) when cash flows are positive as compared to when cash flows are negative. In addition, the F-test shows that the savings rates in total are higher when cash flows are positive compared to when they are negative.

Table 6 illustrates another important point. It is somewhat misleading to simply present savings rates from net equity issues, net debt issues, and cash flows in the aggregate without considering the level of cash flows. The savings rate from cash flows is negative when cash flows are negative (column 2) but is relatively high when cash flows are positive (column 3). In fact, when cash flows are positive they exceed the rate from net equity issues. The savings rates in the aggregate are partly a function of how many firms are profitable versus how many are unprofitable.

We next examine the savings rates from net equity issues, net debt issues, and cash flows at different levels of positive cash flows. To do this we divide all the observations that had positive cash flows into three equal groups (low, medium, and high). We present the savings rates from the three sources for these groups of cash flows in columns 4-8. In column 7 we create a dummy variable that equals one when cash flows are in the high group and zero otherwise. This allows us to compare the savings behavior of firms in the high cash flow group with all other 
firms. In column 8 , we compare the savings behavior of firms in the high cash flow group to those firms in the low and middle groups (in this case the dummy variable equals one when cash flows are in the high group and zero when it is in the low or medium group).

The results from columns 4-8 show that there is a difference between the high cash flow group and the other cash flow groups. The savings coefficient for cash flow from the high cash flow group is much bigger than from all other groups (a difference of .528) and also between the high cash flow group versus the combined low and medium groups (difference of .371). Column 6 suggests that for high cash flow firms, the savings rate from cash flows is almost twice as large as the savings rate from net equity issues and over 22 times the savings rate from net debt issues. It should be recalled that the total amount of net funds sourced (Net_Total) at the high cash flow group is much higher than for any other level of cash flows (Panel $\mathrm{C}$ in Table 2).

For net issues there is a significant difference in the savings rate between the high cash flow group and all other firms but not between the high cash flow group and the combined medium and low positive cash group. There is a significant difference in the savings coefficients from net debt issues between the high cash flow group and all other cash flow groups (-.139) and a smaller but still significant difference between the high cash flow group and the combined medium and low cash flow group (-.086). In summary, our results show that savings rates are influenced by the level of cash flows. For firms that have negative cash flows, relatively more savings comes from net equity and net debt issues. On the other hand, for firms that have very high cash flows (as compared to firms with negative, low or medium cash flows) the savings rate increases dramatically from cash flows.

[Insert Table 6 about here] 


\subsection{Tests for the Hypotheses}

We next examine our hypotheses and these results are presented in Panels A-H of Table 7. In each panel we give the results from four equations. The first equation is our basic equation for testing our hypotheses (equation 2). The second equation includes the two control variables (change in short-term debt and financial development). In these two equations, we focus on the estimated coefficients of the interaction terms between the dummies representing the classifications of observations based on the main variables and sources of cash savings. The last two equations in each panel present the separate results dependant on whether the observation is included in the dummy variable.

\subsubsection{Savings Rates of Financially Constrained and Unconstrained Firms}

We first examine whether savings rates for financially constrained firms are higher than for unconstrained firms (Hypothesis 1). To distinguish between financially constrained and unconstrained firms, we classify firms as constrained (unconstrained) if they are both young and small (old and large). Specifically a firm is designated as constrained (unconstrained) if it is in the bottom (top) third of firms according to age and also according to size. Hadlock and Pierce (2010) compare various measures to detect firms that are financially constrained and conclude that these two measures (size and age) are the best indicators.

In Panel A of Table 7 we present the results of our tests of Hypothesis 1. In Panel A, we use all firm observations that belong to either the small/young group or the big/old group and the dummy variable is equal to one if the observation is part of the small/young group. The results in Panel A suggest that constrained firms (small and young firms) save more (higher total savings rates) than unconstrained firms. The F-test for the combined effect of the three channels is 
significant at the $5 \%$ level in both columns 1 and 2 indicating that the total savings rate is higher for small and young firms.

As an alternative to using size and age to indicate whether a firm is constrained or unconstrained, we examine whether a firm has a debt rating, In unreported results, we find that the total savings rate for firms that do not have a debt rating (constrained firms) is greater than the total savings rate for firms that have a debt rating (unconstrained). These findings support our results using size and age.

\subsubsection{Firm and Market Structure Determinants of Savings Rates}

We next examine various firm variables $(R \& D$, investment opportunities, governance, multinational status and dividends) to see their impact on cash savings rates from net equity issues, net debt issues, and cash flows. In addition, we look at whether market structure (marketbased or bank-based) and investor protection influence savings rates.

\subsubsection{R\&D}

In Panel B of Table 7 we conduct tests to see whether firms that engage in a lot of R\&D save more cash than firms that do less R\&D. We examine this question by interacting variables for net equity issue, net debt issues and cash flow variables with $R \& D$. We classify firms into two groups - (1) those who report zero $R \& D$ or who have missing values for $R \& D$ in a given year and (2) those who report positive values for $R \& D$ in a given year. Firm observations that report a positive value for $R \& D$ represent the dummy variable.

The results in Panel B indicate that firms that do more R\&D save more cash than firms that do less R\&D (the interaction terms are all positive and significant). In addition F-tests on the sum of all three coefficients are significant at the one percent level. We repeated our analysis 
using only observations where the firm explicitly reported a number for $R \& D$ (missing $R \& D$ numbers were excluded) and the results were the same.

Our findings are consistent with the hypothesis that firms that do a lot of R\&D, in general, need to continue to do R\&D (their business success depends on successful R\&D) and these firms save more cash now so that in the event of financial hardships in the future or the unavailability/high costs of future financing, they will have the necessary funds to continue to do R\&D.

\subsubsection{Market-to-Book (MB)}

We use MB ratios as proxies for investment opportunities. Firms with high market-tobook ratios should worry about not being able to fund future worthwhile investment opportunities and thus would want to save more now in order to be able to invest in those worthwhile opportunities in the future. We expect that savings rates in total will be greater for firms with high $\mathrm{MB}$ ratios than for firms with low $\mathrm{MB}$ ratios. We analyze only firm observations in the top and bottom tercile. We create a dummy variable in Panel $\mathrm{C}$ that equals one when the market-tobook ratio is in the top third of all observations and equals zero otherwise.

Panel $\mathrm{C}$ presents the findings for MB ratios.. The F-tests show that firms with high market-to-book ratios save more than firms with low MB ratios. Our evidence is consistent with the idea (hypothesis 3) that firms with better investment opportunities save more than firms with worse investment opportunities.

Market-to-book ratios have also been used as indicators of market timing. High MB ratios would then indicate that firms that had high or unusually high valuations might issue equity to take advantage of these high valuations. The savings rate from net issues would be higher because firms were issuing equity not only for current needs but also to take advantage of the high valuations. Our results then are also consistent with a market timing explanation for saving 
from net issues. Kim and Weisbach (2008) provide evidence for this hypothesis using a sample of IPOs and SEOs.

\subsubsection{Dividends}

In Panel $\mathrm{D}$ we investigate the impact of dividends on savings rates. Firms that pay dividends would appear not to be constrained and in many cases would seem that they already have adequate resources to cover future contingencies. These firms could always increase their savings rates by decreasing their dividends, although there are costs in doing that. It would be expected that the more the firm paid dividends, the smaller the need to save and hence the smaller the savings rates. We create a dummy variable in Panel D that equals one if the firm does not pay a dividend in a given year and equals zero otherwise.

Our findings from Panel D provide support for the hypothesis that non dividend paying firms having higher savings ratios. The F-tests are significant at the one percent level.

\subsubsection{Market-based countries versus bank-based countries}

We next examine whether market structure (market-based or bank-based) affects firms' savings rates. If one structure offers less external financing than another, firms in the environment with less access to external markets will want to save more so that they will not be shut out of future investment opportunities. From Panel A in Table 2, firms in bank-based countries sourced fewer outside funds (net equity issues and net debt issues) than did firms in market-based countries funds $\left(.035^{8} \text { versus } .107\right)^{9}$. We conjecture then that the total savings rate should be higher for bank-based countries than for market-based countries.

\footnotetext{
${ }^{8}$ This is the sum of Net_Issue (.024 vs 0.09) and Net_Debt (.011 vs 0.017).

${ }^{9}$ One could argue that the need for external funds should be lower during our period of study for firms in bank-based countries because the average cash flow is higher for these firms. However, the clear difference in external funds acquired may indicate that firms in bank-based countries may have troubles when their cash flows become less.
} 
Panel E presents our findings. In Panel E the dummy variable equals one for firms residing in bank-based countries and zero for firms in market-based countries. The interaction terms are all significantly positive. The F-tests are all significant at the one percent level and suggests that firms in bank-based countries have higher savings rates than firms in market-based ones.

\subsubsection{Investor Protection}

We look next at whether firms from countries that provide better protection to investors and creditors save less than firms residing in countries that offer less protection. More protection should increase the amount of funds that investors/creditors are willing to supply and thus allow firms to save less because they are not concerned as much about obtaining future funds.

We test this hypothesis in Panel F. Common law countries are presumed to have greater investor protection for both creditors and outside investors as well as have better enforcement mechanisms (La Porta et al., 2008). As a result we construct a dummy variable that equals one if the firm is located in a civil law country and zero otherwise.

The findings indicate that firms in civil law countries save more than firms in common law countries. The F-tests are very significant.

\subsubsection{Governance}

We look at whether governance influences savings rates. Key ingredients of good governance are effective monitoring by large shareholders and the alignment of shareholder interest with ownership interest. We have data on closely held shares which represents shares held by insiders and also by individuals that own five percent or more of a firm's stock. High numbers for this variable indicate greater monitoring and/or closer alignment of shareholder 
interests with those of ownership ${ }^{10}$ and low numbers suggest little monitoring on behalf of large shareholders and less alignment of interests of shareholders with owners.

In Panel $G$ we analyze the effect of governance on savings rates. We divide all of our observations for closely held shares into three groups (high, medium, and low). We examine only the high and low groups and create a dummy variable that equals one when the observation is in the high group of closely held shares. We argued previously that better governance should be associated with greater savings rates.

Our results suggest that the amount of closely held shares does influence corporate savings rates but our findings are just the opposite of what we expected. Apparently, firms that have little monitoring/alignment of interests save more. We are unable to provide a solid rationale for this finding.

\subsubsection{Multinational Status}

In this section we examine whether multinationals save more or less than domestic firms. We define multinationals as firms with a ratio of foreign sales to total sales of at least $25 \%$ and domestic firms as companies with a corresponding percentage of less than or equal to one percent. Firms with foreign sales percentages between one and twenty five percent are excluded from this analysis, as we want to have a big distinction between domestic and multinational firms.

In Panel $\mathrm{H}$ we create a dummy variable that equals one when the firm is defined to be a multinational firm and zero when the firm is a domestic firm. Our findings are very clear. Multinationals save more than domestic firms. The interaction terms for all savings channels are positive and significant. The F-tests are similarly very significant (both at the one percent level). We conjecture that multinationals save more than domestic firms because of the added

\footnotetext{
${ }^{10}$ Unfortunately our data does not allow us to separate out the monitoring aspect from the alignment part.
} 
complexity of their operations. Multinationals save more because more funds are needed for precautionary purposes.

\author{
[Insert Table 7 about here]
}

\title{
4.5 Individual Savings Coefficients
}

In the previous section we analyzed the net (overall) effect of the coefficients from the three savings channels. In this section we explore the individual savings coefficients.

If we disregard the results from Panel G since our findings in that panel are the opposite of what was expected, an inspection of the remaining seven panels in Table 7 reveals that there are only two instances (both involving cash flow) out of a total of 21 where one of the interaction terms has a significant negative $\operatorname{sign}^{11}$. It should be recalled that the expected coefficients on the interaction terms are positive ${ }^{12}$. Based on our limited sample of seven panels, firms appear to increase savings simultaneously from many channels as opposed to increasing savings from only one. For example, companies engaged in $R \& D$ save more than firms than do not do $R \& D$ and those firms doing R\&D save more from each source of funds (net issues, net debt, and cash flows). Another observation from the seven panels is that when firms increase savings overall, savings from net equity always increases significantly.

\subsection{Impact of Size, Financial Development, and Changes in Short-term Debt on Changes in Cash and Short-term Investments}

\footnotetext{
${ }^{11}$ The coefficient on the interactive term Net_Debt*High MB is negative but not significant.

${ }^{12}$ If we include the results of Panel G then there would be only four instances (still a small number) out of 24 where there was a significant negative coefficient on an interactive term.
} 
The coefficient for size has generally a significant positive sign in our study, implying that larger firms generally increase cash and short-term investments more than smaller firms. These results are similar to those reported for US firms in McLean (2011).

Financial development has a generally positive impact on the ability of firms to increase their cash and short-term investments. Changes in short-term debt, on the other hand, have generally a negative influence on changes in cash and short-term investments, implying that short-term debt "substitutes" for cash and short-term investments.

\subsection{Additional Test: Importance of Financial Constraints}

In a previous section, we showed the importance of financial constraints for savings rates. Firms that are financially constrained save more than companies that are not financially constrained. If being financially constrained is a first order determinant of savings rates, then it might be expected that we would find stronger results for the other hypotheses when we limit our samples to constrained firms as opposed to unconstrained companies.

In Table 8, we divide firms into two groups namely those that are constrained and those that are not based on size and age (the same approach used in section 4.3.1). Panel A reports the results with the constrained sample and Panel B does the same for the unconstrained sample. The findings are very strong. For all seven variables, the F-test that the sum of the coefficients on the interactive terms are not equal to zero is much stronger for sample of constrained firms than it is for the sample of unconstrained companies. In fact in only two cases (investment opportunities and multinational statues) is the F-stat even significant in the unconstrained sample. Our results are consistent with the hypothesis that constrained firms save more than unconstrained companies.

[Insert Table 8 about here] 


\subsection{Worldwide Results versus Non-U.S. Results}

U.S. companies account for $37 \%$ of all observations. It is important to see if our findings are being driven by the U.S. observations. As a result, we redo Table 7 with only non-U.S. observations. These findings are reported in Table 9 where we present the results for the second regression for all eight panels in Table 7.

With one exception the conclusions reached for the entire sample are applicable for the sample of non-U.S. companies. The one exception involves our governance variable (closely held shares). For the entire sample higher savings was associated with firms that had small amounts of closely held shares while for the non-U.S. sample greater total savings are correlated with firms that have more closely held shares.

[Insert Table 9 about here]

\subsection{Additional Tests: Gross Equity Issues and Gross Debt Issues Instead of Net Equity and}

\section{Debt Issues}

We performed an additional test on our data. We substituted gross equity issues for net equity issues and gross debt issues for net debt issues. Our main conclusions remain the same. The most noticeable difference involves the size of debt coefficient. Using gross debt the magnitude of the savings coefficient is roughly half the size of the coefficient when net debt issues are employed. The coefficient of gross equity is similar to the one from net equity.

\section{Conclusions}

The purpose of our paper is to examine savings rates from three sources - net equity issues, net debt issues, and cash flow. Previous research has tended to examine only one channel of savings at a time. Our research, in contrast, examines these three channels at the same time. 
We find aggregate savings rates from the three channels are misleading because savings rates depend on the level of cash flows. Aggregate savings rates from the various channels depend on the percentage of firms that have high and/or negative cash flows. For negative cash flows, savings rates from net equity and net debt are much higher than the savings rate from cash flows which are often negative. On the other hand, for high cash flow firms the savings rates from cash flows are much higher than for either net equity issues or net debt issues.

We observe that constrained firms have higher savings rates in total than unconstrained firms. Our findings are consistent with the hypothesis that constrained firms worry about the possibility of not being able to fund future investments and thus save more now to minimize this problem. The issue of constrained versus unconstrained appears to be a first order determinant of savings rates.

We observe that firms appear to save from multiple sources as opposed to relying on only one source of funds. We find that savings rates depend positively on $R \& D$, investment opportunities, multinational status, and whether firms reside in civil law countries and negatively on whether firms pay dividends. We find that firms from bank-based countries save more than firms from market-based countries. We also do not observe a consistent significant relationship between governance and the total savings rate. Overall these results suggest that firms that have critical activities or important opportunities in the future save more now to make sure they can perform those activities later. In addition, firms that reside in countries with less access to external financing save more now because they cannot be sure of getting adequate funding in the future. On the other hand, firms that appear to have access to enough funding in the future save less now because the need to save is less. 


\section{References}

Almeida, H., Campello, M., Weisbach, M., 2004. The cash flow sensitivity of cash. Journal of Finance 59, 1777-1804.

Bates, T.W., Kahle, K.M., Stulz, R.M., 2009. Why do U.S. firms hold more cash than they use to? Journal of Finance 64, 1985-2021.

Dittmar, A., Mahrt-Smith, J., 2007. Corporate governance and the value of cash holdings. Journal of Financial Economics 83, 599-634.

Dittmar, A., Mahrt-Smith, J., Servaes, H., 2003. International corporate governance and corporate cash holdings. Journal of Financial and Quantitative Analysis 38, 111-133.

Duchin, R., 2010. Cash holdings and corporate diversification. The Journal of Finance 65, 955992.

Duchin, R., Ozbas, O., Sensoy, B.A., 2010. Costly external finance, corporate investment, and the subprime mortgage credit crisis. Journal of Financial Economics 97, 418-435.

Ferreira, M., Vilela A., 2004. Why do firms hold cash? Evidence from EMU countries. European Financial Management 10, 295-319.

Hadlock, C. Pierce, J., 2010. New evidence on measuring financial constraints: moving beyond the KZ index. Review of Financial Studies 23, 1909-1940.

Harford, J., Mansi, S.A., Maxwell, W.F., 2008. Corporate governance and firm cash holdings in the US. Journal of Financial Economics 87, 535-555.

Gatchev, Y., Spindt, P., Tarhan, V., 2009. How do firms finance their investments? The relative importance of equity issuance and debt contracting costs. Journal of Corporate Finance 15, 179-195.

Khurana, I., Martin, X., Pereira, R., 2006. Financial development and the cash flow sensitivity of cash. Journal of Financial and Quantitative Analysis 41, 787-807. 
Kim, W., Weisbach, M., 2008. Motivations for public equity offers: An international perspective. Journal of Financial Economics 87, 281-307.

Kusnadi, Y., Wei, J.K.C., 2011. The determinants of corporate cash management policies: Evidence from around the world. Journal of Corporate Finance 17, 725-740.

La Porta, R., Lopez-De-Silanes, F., Shleifer, A., 2008. The economic consequences of legal origins. Journal of Economic Literature 46, 285-332.

Mclean, R., 2011. Share Issuance and cash savings. Journal of Financial Economics 99, 693-715.

McLean, R., Zhao, M., 2011. Share issuance and cash savings: international evidence, Working Paper.

Opler, T., Pinkowitz, L., Stulz, R., Williamson, R., 1999. The determinants and implications of corporate cash holdings. Journal of Financial Economics 52, 3-46.

Pinkowitz, L., Stulz, R., Williamson, R., 2012. Multinationals and the huge cash holdings puzzle. NBER Working Paper 18120.

Riddick, L., Whited, T., 2009. The corporate propensity to save. Journal of Finance 64. 17291766. 
Table 1: Definitions of Variables

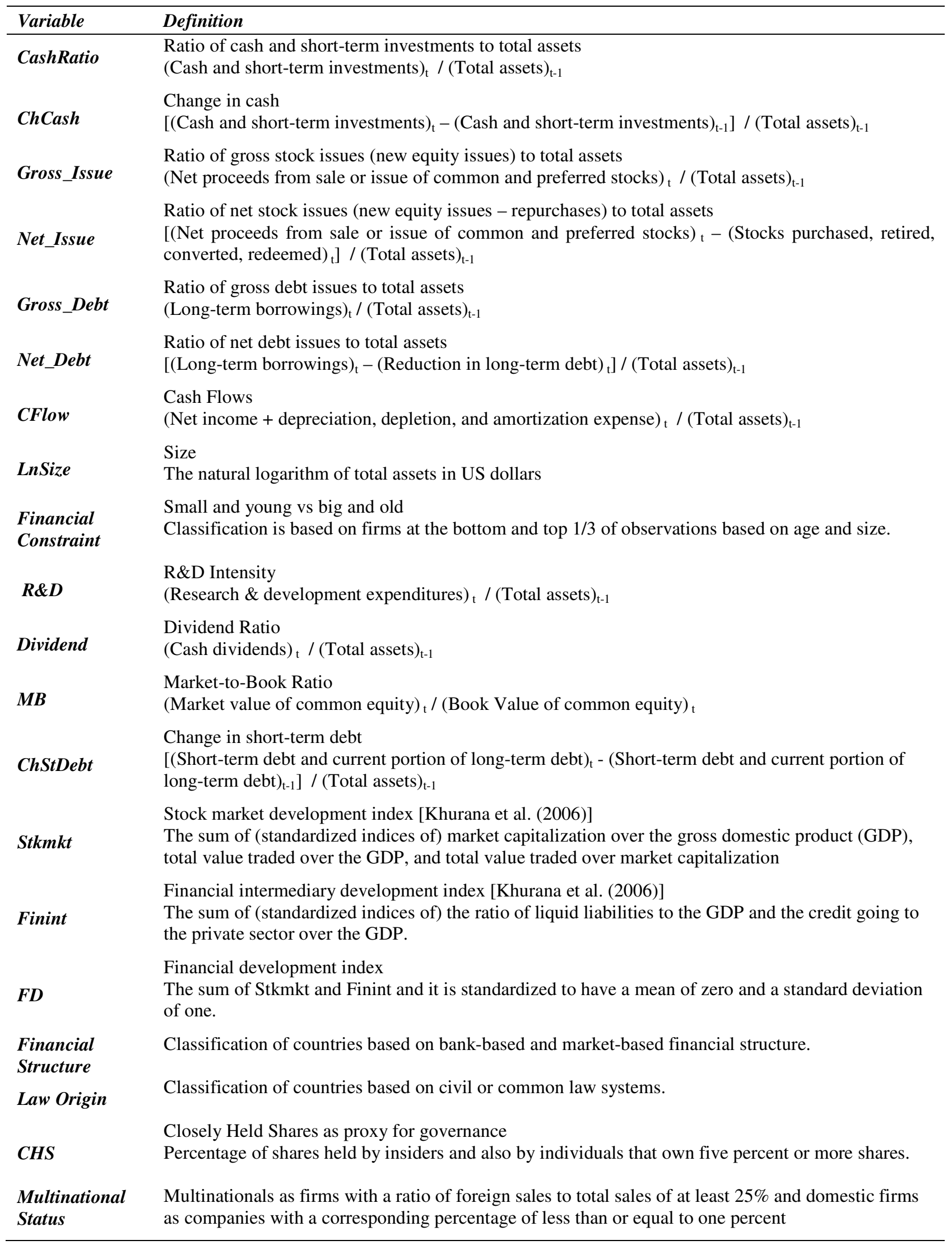


Table 2: Descriptive Statistics

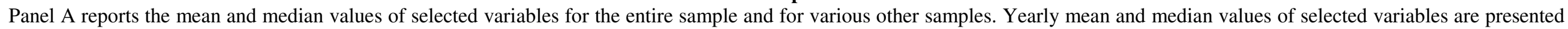

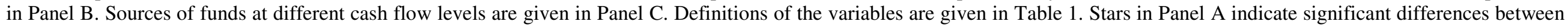
US and Non-US firms or between bank and market- based countries, and ***,**, * denote statistical significance at the $1 \%, 5 \%$, and $10 \%$ levels, respectively.

Panel A: Summary statistics for all observations

\begin{tabular}{|c|c|c|c|c|c|c|c|c|c|c|c|c|c|c|c|}
\hline & \multicolumn{3}{|c|}{ ALL SAMPLE } & \multicolumn{3}{|c|}{ US FIRMS } & \multicolumn{3}{|c|}{ NON-US FIRMS } & \multicolumn{3}{|c|}{ BANK-BASED } & \multicolumn{3}{|c|}{ MARKET-BASED } \\
\hline & \# of obs & Mean & Median & \# of obs & Mean & Median & \# of obs & Mean & Median & \# of obs & Mean & Median & \# of obs & Mean & Median \\
\hline CashRatio & 281429 & 0.195 & 0.107 & 105155 & 0.229 & 0.113 & 176274 & $0.175 * * *$ & $0.104 * * *$ & 62264 & 0.174 & 0.118 & 218458 & $0.201 * * *$ & $0.101 *$ \\
\hline ChCash & 281429 & 0.025 & 0.002 & 105155 & 0.028 & 0.002 & 176274 & $0.023 * * *$ & $0.003 * * *$ & 62264 & 0.019 & 0.003 & 218458 & $0.026 * * *$ & $0.002 * * *$ \\
\hline Gross_Issue & 281429 & 0.079 & 0.000 & 105155 & 0.112 & 0.005 & 176274 & $0.060 * * *$ & $0.000 * * *$ & 62264 & 0.026 & 0.000 & 218458 & $0.094 * * *$ & $0.001 * * *$ \\
\hline Gross_Debt & 281429 & 0.074 & 0.001 & 105155 & 0.090 & 0.000 & 176274 & $0.065 * * *$ & 0.003 & 62264 & 0.066 & 0.011 & 218458 & $0.076 * * *$ & $0.000 * * *$ \\
\hline Net_Issue & 281429 & 0.075 & 0.000 & 105155 & 0.105 & 0.001 & 176274 & $0.057 * * *$ & $0.000 * * *$ & 62264 & 0.024 & 0.000 & 218458 & $0.090 * * *$ & $0.000 * * *$ \\
\hline Net_Debt & 281429 & 0.016 & 0.000 & 105155 & 0.018 & 0.000 & 176274 & $0.014 * * *$ & $0.000 * * *$ & 62264 & 0.011 & 0.000 & 218458 & $0.017 * * *$ & $0.000 * * *$ \\
\hline CFlow & 281429 & 0.001 & 0.071 & 105155 & -0.076 & 0.060 & 176274 & $0.047 * * *$ & $0.076 * * *$ & 62264 & 0.074 & 0.074 & 218458 & $-0.020 * * *$ & $0.070 * * *$ \\
\hline LnSize & 281429 & 4.999 & 5.074 & 105155 & 4.705 & 4.800 & 176274 & $5.175^{* * *}$ & $5.199 * * *$ & 62264 & 5.975 & 5.969 & 218458 & $4.720 * * *$ & $4.733 * * *$ \\
\hline$R \& D$ & 281429 & 0.023 & 0.000 & 105155 & 0.043 & 0.000 & 176274 & $0.012 * * *$ & $0.000 * * *$ & 62264 & 0.014 & 0.000 & 218458 & $0.026 * * *$ & $0.000 * * *$ \\
\hline Dividend & 278890 & 0.012 & 0.000 & 104989 & 0.007 & 0.000 & 173901 & $0.015^{* * *}$ & $0.006^{* * *}$ & 60128 & 0.013 & 0.006 & 218056 & $0.011 * * *$ & $0.000 * * *$ \\
\hline$M B$ & 261503 & 2.203 & 1.497 & 93674 & 2.562 & 1.798 & 167829 & $2.002 * * *$ & $1.375^{* * *}$ & 58956 & 1.912 & 1.396 & 201909 & $2.287 * * *$ & $1.538 * * *$ \\
\hline
\end{tabular}


Panel B: Summary statistics by year

\begin{tabular}{|c|c|c|c|c|c|c|c|c|c|c|c|c|c|c|c|}
\hline \multirow[b]{2}{*}{ Year } & \multirow[b]{2}{*}{ \# of obs. } & \multicolumn{2}{|c|}{ ChCash } & \multicolumn{2}{|c|}{ Gross_Issue } & \multicolumn{2}{|c|}{ Net_Issue } & \multicolumn{2}{|c|}{ Gross_Debt } & \multicolumn{2}{|c|}{ Net_Debt } & \multicolumn{2}{|c|}{ CFlow } & \multicolumn{2}{|c|}{ LnSize } \\
\hline & & Mean & Median & Mean & Median & Mean & Median & Mean & Median & Mean & Median & Mean & Median & Mean & Median \\
\hline 1991 & 5655 & 0.014 & 0.001 & 0.034 & 0.000 & 0.032 & 0.000 & 0.053 & 0.006 & 0.012 & 0.000 & 0.078 & 0.084 & 5.508 & 5.417 \\
\hline 1992 & 6422 & 0.018 & 0.002 & 0.040 & 0.000 & 0.038 & 0.000 & 0.058 & 0.006 & 0.007 & 0.000 & 0.077 & 0.086 & 5.462 & 5.389 \\
\hline 1993 & 6845 & 0.024 & 0.003 & 0.048 & 0.000 & 0.045 & 0.000 & 0.062 & 0.005 & 0.007 & -0.001 & 0.081 & 0.089 & 5.426 & 5.336 \\
\hline 1994 & 7308 & 0.020 & 0.002 & 0.050 & 0.001 & 0.048 & 0.000 & 0.066 & 0.006 & 0.012 & 0.000 & 0.091 & 0.098 & 5.495 & 5.443 \\
\hline 1995 & 9051 & 0.018 & 0.001 & 0.052 & 0.001 & 0.049 & 0.000 & 0.071 & 0.008 & 0.017 & 0.000 & 0.082 & 0.098 & 5.435 & 5.375 \\
\hline 1996 & 10243 & 0.026 & 0.003 & 0.065 & 0.001 & 0.062 & 0.000 & 0.083 & 0.013 & 0.022 & 0.000 & 0.076 & 0.094 & 5.411 & 5.341 \\
\hline 1997 & 11385 & 0.021 & 0.002 & 0.067 & 0.001 & 0.064 & 0.000 & 0.089 & 0.012 & 0.026 & 0.000 & 0.053 & 0.089 & 5.279 & 5.218 \\
\hline 1998 & 12377 & 0.019 & 0.000 & 0.075 & 0.001 & 0.070 & 0.000 & 0.089 & 0.010 & 0.026 & 0.000 & 0.015 & 0.078 & 5.111 & 5.078 \\
\hline 1999 & 13906 & 0.032 & 0.001 & 0.104 & 0.001 & 0.099 & 0.000 & 0.082 & 0.003 & 0.020 & 0.000 & -0.026 & 0.069 & 4.750 & 4.810 \\
\hline 2000 & 15239 & 0.035 & 0.002 & 0.126 & 0.001 & 0.121 & 0.000 & 0.072 & 0.001 & 0.014 & 0.000 & -0.033 & 0.063 & 4.865 & 5.003 \\
\hline 2001 & 16606 & 0.005 & -0.001 & 0.070 & 0.000 & 0.067 & 0.000 & 0.066 & 0.000 & 0.010 & 0.000 & -0.045 & 0.048 & 4.704 & 4.805 \\
\hline 2002 & 17708 & 0.009 & 0.000 & 0.064 & 0.000 & 0.060 & 0.000 & 0.060 & 0.000 & 0.004 & 0.000 & -0.037 & 0.048 & 4.629 & 4.716 \\
\hline 2003 & 17911 & 0.027 & 0.004 & 0.071 & 0.000 & 0.067 & 0.000 & 0.067 & 0.000 & 0.009 & 0.000 & -0.021 & 0.059 & 4.670 & 4.775 \\
\hline 2004 & 18293 & 0.040 & 0.007 & 0.103 & 0.001 & 0.099 & 0.000 & 0.074 & 0.000 & 0.013 & 0.000 & -0.014 & 0.071 & 4.753 & 4.842 \\
\hline 2005 & 18859 & 0.036 & 0.005 & 0.101 & 0.001 & 0.096 & 0.000 & 0.079 & 0.000 & 0.017 & 0.000 & -0.014 & 0.074 & 4.806 & 4.888 \\
\hline 2006 & 18933 & 0.039 & 0.006 & 0.106 & 0.001 & 0.100 & 0.000 & 0.085 & 0.000 & 0.022 & 0.000 & -0.014 & 0.075 & 4.914 & 5.025 \\
\hline 2007 & 19690 & 0.038 & 0.006 & 0.108 & 0.001 & 0.103 & 0.000 & 0.088 & 0.001 & 0.026 & 0.000 & -0.008 & 0.077 & 4.998 & 5.098 \\
\hline 2008 & 19107 & 0.007 & -0.001 & 0.069 & 0.000 & 0.064 & 0.000 & 0.081 & 0.002 & 0.024 & 0.000 & -0.018 & 0.061 & 5.070 & 5.173 \\
\hline 2009 & 18422 & 0.019 & 0.004 & 0.053 & 0.000 & 0.050 & 0.000 & 0.065 & 0.000 & 0.008 & 0.000 & -0.018 & 0.052 & 5.078 & 5.200 \\
\hline 2010 & 17469 & 0.030 & 0.006 & 0.069 & 0.000 & 0.065 & 0.000 & 0.067 & 0.000 & 0.010 & 0.000 & 0.009 & 0.071 & 5.274 & 5.417 \\
\hline
\end{tabular}


Panel C: Sources of cash for cash flow levels

\begin{tabular}{|c|c|c|c|c|c|c|c|c|c|c|c|c|c|c|c|}
\hline & \multicolumn{3}{|c|}{ Cflow (-) } & \multicolumn{3}{|c|}{ Cflow (+) } & \multicolumn{3}{|c|}{ Low Cflow (+) } & \multicolumn{3}{|c|}{ Middle Cflow (+) } & \multicolumn{3}{|c|}{ High Cflow (+) } \\
\hline & \# of obs & Mean & Median & \# of obs & Mean & Median & \# of obs & Mean & Median & \# of obs & Mean & Median & \# of obs & Mean & Median \\
\hline ChCash & 72914 & 0.017 & -0.007 & 208515 & 0.028 & 0.005 & 69518 & 0.003 & 0.000 & 69341 & 0.014 & 0.004 & 69656 & 0.066 & 0.025 \\
\hline Gross_Issue & 72914 & 0.191 & 0.004 & 208515 & 0.040 & 0.000 & 69518 & 0.021 & 0.000 & 69341 & 0.026 & 0.000 & 69656 & 0.073 & 0.002 \\
\hline Gross_Debt & 72914 & 0.070 & 0.000 & 208515 & 0.076 & 0.007 & 69518 & 0.069 & 0.012 & 69341 & 0.077 & 0.013 & 69656 & 0.081 & 0.000 \\
\hline Net_Issue & 72914 & 0.188 & 0.003 & 208515 & 0.036 & 0.000 & 69518 & 0.019 & 0.000 & 69341 & 0.022 & 0.000 & 69656 & 0.067 & 0.000 \\
\hline Net_Debt & 72914 & 0.020 & 0.000 & 208515 & 0.014 & 0.000 & 69518 & 0.009 & 0.000 & 69341 & 0.014 & 0.000 & 69656 & 0.019 & 0.000 \\
\hline CFlow & 72914 & -0.329 & -0.196 & 208515 & 0.117 & 0.100 & 69518 & 0.042 & 0.044 & 69341 & 0.101 & 0.100 & 69656 & 0.207 & 0.193 \\
\hline Gross_Total & 72914 & -0.068 & -0.045 & 208515 & 0.233 & 0.163 & 69518 & 0.133 & 0.072 & 69341 & 0.204 & 0.134 & 69656 & 0.361 & 0.274 \\
\hline Net_Total & 72914 & -0.121 & -0.074 & 208515 & 0.167 & 0.118 & 69518 & 0.070 & 0.045 & 69341 & 0.137 & 0.106 & 69656 & 0.292 & 0.224 \\
\hline
\end{tabular}


Table 3: Cash savings for the entire period and before and after the crisis period

This table reports estimates of OLS regressions for the change in cash (ChCash) controlling for country, year and industry effects. Year dummies are excluded in models where a dummy for the crisis years is introduced. $\boldsymbol{D}_{\mathbf{2 0 0 7 - 1 0}}$ is a dummy variable that takes a value of 1 for the years $2007-2010$ and 0 for the other years. Robust standard errors are in brackets. Definitions of the other variables are given in Table 1 . The symbols $* * *, * *, *$ denote statistical significance at the $1 \%, 5 \%$, and $10 \%$ levels, respectively.

\begin{tabular}{|c|c|c|c|c|c|c|}
\hline \multirow[b]{2}{*}{ Constant } & \multicolumn{4}{|c|}{ 1991-2010 } & \multirow{3}{*}{$\begin{array}{c}2007-2010 \\
-0.034^{* *} \\
{[0.015]}\end{array}$} & \multirow{3}{*}{$\begin{array}{c}1991-2006 \\
-0.019 * \\
{[0.010]}\end{array}$} \\
\hline & $-0.019 * *$ & $-0.015^{*}$ & $-0.016^{*}$ & $-0.017 *$ & & \\
\hline & [0.009] & {$[0.009]$} & {$[0.009]$} & {$[0.009]$} & & \\
\hline \multirow[t]{2}{*}{ Net_Issue } & $0.362 * * *$ & $0.362 * * *$ & $0.365^{* * *}$ & $0.365^{* * *}$ & $0.352 * * *$ & $0.364 * * *$ \\
\hline & [0.003] & [0.003] & [0.003] & [0.003] & [0.006] & [0.003] \\
\hline \multirow[t]{2}{*}{ Net_Debt } & $0.107 * * *$ & $0.101 * * *$ & $0.103 * * *$ & $0.097 * * *$ & $0.117 * * *$ & $0.097 * * *$ \\
\hline & [0.004] & [0.004] & [0.004] & [0.005] & [0.009] & {$[0.005]$} \\
\hline \multirow[t]{2}{*}{ CFlow } & $0.116^{* * *}$ & $0.117 * * *$ & $0.112 * * *$ & $0.113 * * *$ & $0.130 * * *$ & $0.113 * * *$ \\
\hline & [0.002] & [0.002] & [0.002] & [0.002] & [0.004] & [0.002] \\
\hline \multirow{2}{*}{ LnSize } & $0.002 * * *$ & $0.002 * * *$ & $0.002 * * *$ & $0.002 * * *$ & $0.002 * * *$ & $0.002 * * *$ \\
\hline & {$[0.000]$} & [0.000] & {$[0.000]$} & [0.000] & {$[0.000]$} & {$[0.000]$} \\
\hline \multirow[t]{2}{*}{ ChStdebt } & & $-0.034 * * *$ & & $-0.031 * * *$ & $-0.030 * * *$ & $-0.034 * * *$ \\
\hline & & [0.004] & & [0.004] & {$[0.011]$} & [0.005] \\
\hline \multirow[t]{2}{*}{$F D$} & & 0.000 & & $0.001 * * *$ & 0.001 & -0.001 \\
\hline & & {$[0.001]$} & & {$[0.000]$} & {$[0.002]$} & {$[0.001]$} \\
\hline \multirow{2}{*}{$D_{2007-10}$} & & & 0.000 & $-0.001 *$ & & \\
\hline & & & {$[0.001]$} & {$[0.001]$} & & \\
\hline \multirow{2}{*}{ Net_Issue* $D_{2007-10}\left(\beta_{\mathrm{E}}\right)$} & & & $-0.013 * *$ & $-0.012 * *$ & & \\
\hline & & & {$[0.006]$} & {$[0.006]$} & & \\
\hline \multirow[t]{2}{*}{ Net_Debt* $\boldsymbol{D}_{2007-10}\left(\beta_{\mathrm{D}}\right)$} & & & 0.013 & 0.013 & & \\
\hline & & & [0.010] & [0.010] & & \\
\hline \multirow[t]{2}{*}{ Cflow $^{*} * \boldsymbol{D y}_{2007-10}\left(\beta_{\mathrm{C}}\right)$} & & & $0.016 * * *$ & $0.016 * * *$ & & \\
\hline & & & [0.004] & [0.004] & & \\
\hline Adjusted R-sq & 0.252 & 0.253 & 0.25 & 0.25 & 0.232 & 0.258 \\
\hline \# Of Observations & 235069 & 235069 & 235069 & 235069 & 43207 & 191862 \\
\hline$F$ Test $\left(\beta_{\mathrm{E}}\right)+\left(\beta_{\mathrm{D}}\right)+\left(\beta_{\mathrm{C}}\right)=0$ & & & 1.59 & 1.61 & & \\
\hline$F$ Test $\left(\beta_{\mathrm{E}}\right)=\left(\beta_{\mathrm{D}}\right)$ & & & $4.92 * *$ & $4.44 * *$ & $429 * * *$ & $2566 * * *$ \\
\hline$F$ Test $\left(\beta_{\mathrm{E}}\right)=\left(\beta_{\mathrm{C}}\right)$ & & & $24.4 * * *$ & $24.4 * * *$ & $1378 * * *$ & $8055^{* * *}$ \\
\hline$F$ Test $\left(\beta_{\mathrm{D}}\right)=\left(\beta_{\mathrm{C}}\right)$ & & & 0.05 & 0.12 & 1.68 & $10.4 * * *$ \\
\hline
\end{tabular}


Table 4: Annual estimated coefficients of net equity and debt issues and cash flows

This table reports the estimates of OLS regressions for the change in cash (ChCash) by year. All regressions include country and industry fixed effects. Definitions of the variables are given in Table 1 . Robust standard errors are in brackets. The symbols ***,**,* denote statistical significance at the $1 \%, 5 \%$, and $10 \%$ levels, respectively.

\begin{tabular}{|c|c|c|c|c|c|c|c|c|c|c|c|c|}
\hline Year & Constant & StdErr. & Net_Issue & StdErr. & Net_Debt & StdErr. & CFlow & StdErr. & LnSize & StdErr. & $R s q$. & \# of obs. \\
\hline 1991 & 0.015 & [0.012] & $0.297 * * *$ & {$[0.020]$} & $0.067 * * *$ & {$[0.021]$} & $0.127 * * *$ & [0.017] & 0.000 & {$[0.001]$} & 0.225 & 5655 \\
\hline 1992 & -0.001 & [0.024] & $0.347 * * *$ & [0.018] & $0.066 * * *$ & [0.021] & $0.144 * * *$ & [0.015] & 0.000 & [0.001] & 0.294 & 6422 \\
\hline 1993 & 0.009 & [0.021] & $0.293 * * *$ & [0.016] & $0.109 * * *$ & [0.022] & $0.119 * * *$ & [0.015] & 0.000 & [0.001] & 0.283 & 6845 \\
\hline 1994 & 0.013 & [0.041] & $0.305 * * *$ & [0.015] & $0.056 * * *$ & [0.018] & $0.150 * * *$ & [0.015] & $0.001 *$ & [0.001] & 0.268 & 7308 \\
\hline 1995 & -0.003 & [0.027] & $0.391 * * *$ & [0.012] & $0.050 * * *$ & [0.015] & $0.130 * * *$ & [0.012] & $0.003 * * *$ & [0.001] & 0.304 & 9051 \\
\hline 1996 & $-0.026 *$ & [0.014] & $0.382 * * *$ & {$[0.010]$} & $0.062 * * *$ & [0.016] & $0.133 * * *$ & [0.011] & 0.000 & {$[0.001]$} & 0.324 & 10243 \\
\hline 1998 & $-0.031 * *$ & [0.014] & $0.387 * * *$ & [0.010] & $0.057 * * *$ & [0.015] & $0.088 * * *$ & [0.008] & $0.004 * * *$ & [0.001] & 0.287 & 12377 \\
\hline 1999 & $-0.082 * *$ & [0.033] & $0.375 * * *$ & [0.009] & $0.060 * * *$ & [0.015] & $0.061 * * *$ & [0.007] & $0.006 * * *$ & [0.001] & 0.307 & 13906 \\
\hline 2000 & $-0.157 * *$ & [0.068] & $0.339 * * *$ & [0.008] & $0.110 * * *$ & [0.016] & $0.101 * * *$ & {$[0.007]$} & $0.004 * * *$ & [0.001] & 0.271 & 15239 \\
\hline 2001 & $-0.077 * * *$ & {$[0.023]$} & $0.341 * * *$ & [0.009] & $0.126 * * *$ & [0.015] & $0.157 * * *$ & [0.006] & $0.002 * * *$ & {$[0.001]$} & 0.228 & 16606 \\
\hline 2002 & -0.020 & [0.018] & $0.323 * * *$ & [0.010] & $0.177 * * *$ & [0.016] & $0.149 * * *$ & [0.006] & 0.000 & {$[0.000]$} & 0.207 & 17708 \\
\hline 2003 & -0.007 & [0.044] & $0.396 * * *$ & [0.009] & $0.175^{* * *}$ & [0.016] & $0.133 * * *$ & [0.006] & $0.001 * *$ & [0.001] & 0.269 & 17911 \\
\hline 2005 & 0.040 & [0.051] & $0.375 * * *$ & [0.008] & $0.164 * * *$ & {$[0.015]$} & $0.100 * * *$ & [0.006] & $0.001 * *$ & [0.001] & 0.264 & 18859 \\
\hline 2006 & 0.007 & [0.068] & $0.372 * * *$ & [0.007] & $0.119 * * *$ & [0.014] & $0.110 * * *$ & [0.006] & 0.001 & [0.001] & 0.266 & 18933 \\
\hline 2007 & -0.006 & [0.028] & $0.372 * * *$ & [0.007] & $0.133 * * *$ & [0.013] & $0.120 * * *$ & [0.007] & $0.001 *$ & [0.001] & 0.276 & 19690 \\
\hline 2008 & $-0.039 * *$ & [0.017] & $0.342 * * *$ & [0.009] & $0.120 * * *$ & [0.013] & $0.143 * * *$ & [0.006] & $0.002 * * *$ & [0.001] & 0.224 & 19107 \\
\hline 2009 & -0.014 & [0.021] & $0.360 * * *$ & [0.011] & $0.185 * * *$ & {$[0.015]$} & $0.164 * * *$ & {$[0.007]$} & $0.002 * * *$ & [0.001] & 0.220 & 18422 \\
\hline 2010 & $0.035^{*}$ & [0.019] & $0.386 * * *$ & {$[0.010]$} & $0.167 * * *$ & {$[0.016]$} & $0.113 * * *$ & {$[0.008]$} & $0.002 * * *$ & {$[0.001]$} & 0.256 & 17469 \\
\hline
\end{tabular}


Table 5: Sample countries and cash saving

This table reports estimated coefficients of the OLS regressions controlling for industry and year fixed effects for the change in cash (ChCash) by country (Panel A), mean values of variables for sources of cash (Panel B), and average amount of cash saved from each source as percentage of assets (Panel C).

\begin{tabular}{|c|c|c|c|c|c|c|c|c|c|c|}
\hline & \multicolumn{4}{|c|}{ Panel A: Coefficient estimates } & \multicolumn{3}{|c|}{ Panel B: Sources of cash } & \multicolumn{3}{|c|}{ Panel C: Cash saving (\%) } \\
\hline & $\begin{array}{l}\text { \# of } \\
o b s .\end{array}$ & $\begin{array}{r}\text { Net } \\
\text { Issue }\end{array}$ & $\begin{array}{r}\text { Net } \\
\text { Debt }\end{array}$ & CFlow & $\begin{array}{r}\text { Net } \\
\text { Issue }\end{array}$ & $\begin{array}{r}\text { Net } \\
\text { Debt }\end{array}$ & CFlow & $\begin{array}{r}\text { Net } \\
\text { Issue }\end{array}$ & $\begin{array}{c}\text { Net } \\
\text { Debt }\end{array}$ & CFlow \\
\hline ARGENTINA & 579 & 0.379 & 0.068 & 0.095 & 0.010 & 0.010 & 0.087 & 0.38 & 0.07 & 0.83 \\
\hline AUSTRALIA & 13033 & 0.419 & 0.019 & 0.131 & 0.168 & 0.016 & -0.080 & 7.01 & 0.03 & -1.04 \\
\hline AUSTRIA & 551 & 0.569 & 0.114 & 0.241 & 0.019 & 0.016 & 0.082 & 1.11 & 0.18 & 1.98 \\
\hline BELGIUM & 785 & 0.446 & 0.149 & 0.165 & 0.031 & 0.006 & 0.081 & 1.40 & 0.09 & 1.33 \\
\hline BERMUDA & 400 & 0.330 & 0.189 & -0.036 & 0.118 & 0.036 & 0.007 & 3.89 & 0.68 & -0.02 \\
\hline BRAZIL & 2091 & 0.212 & 0.192 & 0.108 & 0.045 & 0.034 & 0.082 & 0.95 & 0.65 & 0.89 \\
\hline CANADA & 10683 & 0.381 & -0.010 & 0.061 & 0.144 & 0.018 & -0.011 & 5.50 & -0.02 & -0.07 \\
\hline CHILE & 1459 & 0.329 & -0.006 & 0.056 & 0.020 & 0.013 & 0.100 & 0.64 & -0.01 & 0.56 \\
\hline CHINA & 7251 & 0.449 & 0.254 & 0.210 & 0.056 & 0.028 & 0.092 & 2.53 & 0.71 & 1.93 \\
\hline COLOMBIA & 319 & 0.633 & 0.277 & 0.243 & 0.014 & 0.019 & 0.087 & 0.87 & 0.54 & 2.12 \\
\hline DENMARK & 1751 & 0.474 & 0.049 & 0.191 & 0.026 & 0.012 & 0.083 & 1.24 & 0.06 & 1.58 \\
\hline EGYPT & 247 & 0.601 & 0.227 & 0.413 & 0.021 & 0.009 & 0.157 & 1.24 & 0.21 & 6.51 \\
\hline FINLAND & 1618 & 0.438 & 0.074 & 0.177 & 0.020 & 0.004 & 0.090 & 0.87 & 0.03 & 1.60 \\
\hline FRANCE & 5999 & 0.425 & 0.164 & 0.191 & 0.021 & 0.008 & 0.078 & 0.87 & 0.13 & 1.48 \\
\hline GERMANY & 4424 & 0.478 & 0.105 & 0.141 & 0.035 & 0.009 & 0.072 & 1.66 & 0.10 & 1.02 \\
\hline GREECE & 478 & 0.219 & 0.044 & 0.222 & 0.032 & 0.034 & 0.073 & 0.70 & 0.15 & 1.63 \\
\hline HONG KONG & 10020 & 0.436 & 0.204 & 0.127 & 0.072 & 0.018 & 0.024 & 3.16 & 0.37 & 0.30 \\
\hline HUNGARY & 256 & 0.262 & 0.001 & 0.099 & 0.033 & 0.013 & 0.086 & 0.87 & 0.00 & 0.85 \\
\hline INDIA & 9277 & 0.255 & 0.083 & 0.128 & 0.040 & 0.038 & 0.099 & 1.02 & 0.32 & 1.27 \\
\hline INDONESIA & 3430 & 0.330 & 0.193 & 0.118 & 0.028 & 0.009 & 0.067 & 0.93 & 0.18 & 0.79 \\
\hline IRELAND & 1333 & 0.436 & 0.158 & 0.147 & 0.087 & 0.023 & 0.022 & 3.77 & 0.36 & 0.33 \\
\hline ISRAEL & 893 & 0.445 & 0.297 & 0.290 & 0.048 & 0.019 & 0.064 & 2.12 & 0.55 & 1.85 \\
\hline ITALY & 2541 & 0.355 & 0.153 & 0.121 & 0.024 & 0.009 & 0.064 & 0.87 & 0.14 & 0.78 \\
\hline JAPAN & 20083 & 0.471 & 0.331 & 0.262 & 0.008 & 0.001 & 0.058 & 0.36 & 0.03 & 1.51 \\
\hline KOREA (SOUTH) & 8633 & 0.400 & 0.159 & 0.208 & 0.039 & 0.023 & 0.060 & 1.54 & 0.37 & 1.25 \\
\hline KUWAIT & 171 & 0.386 & -0.044 & 0.595 & 0.038 & 0.040 & 0.103 & 1.47 & -0.18 & 6.13 \\
\hline LUXEMBOURG & 195 & 0.402 & 0.118 & 0.253 & 0.043 & 0.021 & 0.102 & 1.71 & 0.24 & 2.57 \\
\hline MALAYSIA & 8898 & 0.310 & 0.099 & 0.100 & 0.022 & 0.009 & 0.049 & 0.69 & 0.09 & 0.49 \\
\hline MEXICO & 1837 & 0.152 & 0.113 & 0.137 & 0.020 & 0.012 & 0.087 & 0.30 & 0.14 & 1.19 \\
\hline NETHERLANDS & 2946 & 0.329 & 0.115 & 0.095 & 0.039 & 0.013 & 0.098 & 1.28 & 0.14 & 0.93 \\
\hline NEW ZEALAND & 862 & 0.276 & 0.021 & 0.112 & 0.030 & 0.014 & 0.092 & 0.83 & 0.03 & 1.03 \\
\hline NORWAY & 1750 & 0.398 & 0.027 & 0.184 & 0.058 & 0.026 & 0.073 & 2.33 & 0.07 & 1.34 \\
\hline PAKISTAN & 967 & 0.234 & 0.046 & 0.228 & 0.012 & 0.011 & 0.116 & 0.28 & 0.05 & 2.65 \\
\hline PERU & 501 & 0.311 & 0.017 & 0.195 & 0.014 & 0.017 & 0.134 & 0.43 & 0.03 & 2.61 \\
\hline PHILIPPINES & 1981 & 0.339 & 0.185 & 0.060 & 0.026 & 0.010 & 0.030 & 0.87 & 0.19 & 0.18 \\
\hline POLAND & 810 & 0.402 & -0.013 & 0.121 & 0.054 & 0.017 & 0.103 & 2.16 & -0.02 & 1.25 \\
\hline
\end{tabular}


Table 5 (continued)

\begin{tabular}{|c|c|c|c|c|c|c|c|c|c|c|}
\hline & \multicolumn{4}{|c|}{ Coefficient estimates } & \multicolumn{3}{|c|}{ Sources of cash } & \multicolumn{3}{|c|}{ Cash saving } \\
\hline & $\begin{array}{l}\text { \# of } \\
\text { obs. }\end{array}$ & $\begin{array}{r}\text { Net } \\
\text { Issue }\end{array}$ & $\begin{array}{r}\text { Net } \\
\text { Debt }\end{array}$ & CFlow & $\begin{array}{r}\text { Net } \\
\text { Issue }\end{array}$ & $\begin{array}{r}\text { Net } \\
\text { Debt }\end{array}$ & CFlow & $\begin{array}{r}\text { Net } \\
\text { Issue }\end{array}$ & $\begin{array}{r}\text { Net } \\
\text { Debt }\end{array}$ & CFlow \\
\hline PORTUGAL & 578 & 0.169 & 0.101 & 0.147 & 0.018 & 0.024 & 0.074 & 0.30 & 0.25 & 1.08 \\
\hline RUSSIAN FED. & 386 & 0.372 & 0.261 & 0.300 & 0.041 & 0.046 & 0.144 & 1.51 & 1.21 & 4.33 \\
\hline SAUDI ARABIA & 323 & 0.547 & 0.011 & 0.234 & 0.031 & 0.020 & 0.130 & 1.72 & 0.02 & 3.05 \\
\hline SINGAPORE & 5560 & 0.394 & 0.096 & 0.188 & 0.043 & 0.012 & 0.063 & 1.69 & 0.11 & 1.18 \\
\hline SOUTH AFRICA & 3259 & 0.281 & 0.099 & 0.135 & 0.035 & 0.011 & 0.123 & 0.99 & 0.11 & 1.66 \\
\hline SPAIN & 1035 & 0.263 & 0.074 & 0.015 & 0.020 & 0.019 & 0.083 & 0.52 & 0.14 & 0.12 \\
\hline SRI LANKA & 226 & 0.366 & -0.092 & 0.136 & 0.027 & 0.013 & 0.107 & 0.98 & -0.12 & 1.46 \\
\hline SWEDEN & 2538 & 0.422 & 0.008 & 0.223 & 0.044 & 0.011 & 0.069 & 1.85 & 0.01 & 1.54 \\
\hline SWITZERLAND & 2124 & 0.543 & 0.152 & 0.195 & 0.017 & 0.003 & 0.081 & 0.94 & 0.04 & 1.58 \\
\hline TAIWAN & 6834 & 0.396 & 0.246 & 0.310 & 0.017 & 0.018 & 0.092 & 0.65 & 0.44 & 2.86 \\
\hline THAILAND & 4713 & 0.280 & 0.081 & 0.088 & 0.026 & 0.005 & 0.084 & 0.72 & 0.04 & 0.73 \\
\hline TURKEY & 815 & 0.252 & 0.028 & 0.170 & 0.023 & 0.021 & 0.107 & 0.59 & 0.06 & 1.82 \\
\hline UNITED KINGDOM & 27755 & 0.379 & 0.039 & 0.118 & 0.092 & 0.010 & 0.012 & 3.49 & 0.04 & 0.14 \\
\hline UNITED STATES & 94918 & 0.342 & 0.129 & 0.104 & 0.111 & 0.019 & -0.090 & 3.80 & 0.24 & -0.93 \\
\hline VENEZUELA & 211 & 0.215 & 0.100 & 0.279 & 0.004 & 0.007 & 0.095 & 0.08 & 0.07 & 2.66 \\
\hline ZIMBABWE & 143 & 0.157 & -0.014 & 0.113 & 0.058 & 0.020 & 0.114 & 0.91 & -0.03 & 1.29 \\
\hline OTHER COUNTR. & 959 & 0.432 & 0.179 & 0.210 & 0.031 & 0.022 & 0.110 & 1.34 & 0.39 & 2.32 \\
\hline
\end{tabular}

Other countries are; BAHRAIN (15), BULGARIA (2), CAYMAN ISLANDS (98), CHANNEL ISLANDS (14), CZECH REPUBLIC (105), ESTONIA (25), GHANA (3), ICELAND (44), JORDAN (98), LIECHTENSTEIN (7), LITHUANIA (9), MOROCCO (88), OMAN (75), ROMANIA (5), QATAR (94), SLOVAKIA (28), SLOVENIA (79), UNITED ARAB EMIRATES (105), VIETNAM (31), VIRGIN ISLANDS (BRITIAN, 34). 
Table 6: Cash savings at different levels of cash flows

This table reports estimates of OLS regressions for the change in cash (ChCash) controlling for country, year and industry effects. Standard errors given in brackets are clustered at the firm level. Low, middle, and high Cflow subsamples represent the bottom, middle, and top $1 / 3$ observations with positive cash flows. $\boldsymbol{D}_{\text {cflow }}$ is a dummy variable representing different groups in the Table: In column 1, it takes a value of 1 for observations having positive cash flows and 0 for observations having negative cash flows. In column 8 , it takes a value of 1 for observations having high positive cash flows, and 0 otherwise. In column 9 , it takes a value of 1 for observations having high positive cash flows and 0 for observations having low and middle positive cash flows. Definitions of the other variables are given in Table 1 . The symbols $* * *, * *, *$ denote statistical significance at the $1 \%, 5 \%$, and $10 \%$ levels, respectively.

\begin{tabular}{|c|c|c|c|c|c|c|c|c|}
\hline & All observations & Cflow (-) & Cflow (+) & $\begin{array}{c}\text { Low } \\
\text { Cflow (+) } \\
(0.073)\end{array}$ & $\begin{array}{c}\text { Middle } \\
\text { Cflow (+) } \\
(0.134)\end{array}$ & $\begin{array}{c}\text { High } \\
\text { Cflow (+) } \\
(0.286)\end{array}$ & $\begin{array}{l}\text { High vs } \\
\text { All }\end{array}$ & $\begin{array}{l}\text { High vs Low } \\
\text { and Middle }\end{array}$ \\
\hline & $(1)$ & $(2)$ & (3) & (4) & (5) & (6) & $(7)$ & $(8)$ \\
\hline Constant & $\begin{array}{c}-0.041 * * * \\
{[0.008]}\end{array}$ & $\begin{array}{c}-0.125^{* * * *} \\
{[0.020]}\end{array}$ & $\begin{array}{c}-0.008 \\
{[0.008]}\end{array}$ & $\begin{array}{c}-0.009 \\
{[0.014]}\end{array}$ & $\begin{array}{c}-0.043 \\
{[0.033]}\end{array}$ & $\begin{array}{c}-0.038 * * * \\
{[0.014]}\end{array}$ & $\begin{array}{c}-0.035 * * * \\
{[0.008]}\end{array}$ & $\begin{array}{c}-0.005 \\
{[0.008]}\end{array}$ \\
\hline Net_Issue & $\begin{array}{c}0.356 * * * \\
{[0.004]}\end{array}$ & $\begin{array}{c}0.349 * * * \\
{[0.004]}\end{array}$ & $\begin{array}{c}0.303 * * * \\
{[0.003]}\end{array}$ & $\begin{array}{c}0.297 * * * \\
{[0.009]}\end{array}$ & $\begin{array}{c}0.296 * * * \\
{[0.008]}\end{array}$ & $\begin{array}{c}0.296^{* * *} * \\
{[0.004]}\end{array}$ & $\begin{array}{c}0.349 * * * \\
{[0.003]}\end{array}$ & $\begin{array}{c}0.295 * * * \\
{[0.006]}\end{array}$ \\
\hline Net_Debt & $\begin{array}{c}0.187 * * * \\
{[0.009]}\end{array}$ & $\begin{array}{c}0.168 * * * \\
{[0.009]}\end{array}$ & $\begin{array}{c}0.052 * * * \\
{[0.004]}\end{array}$ & $\begin{array}{c}0.084 * * * \\
{[0.006]}\end{array}$ & $\begin{array}{c}0.082 * * * \\
{[0.006]}\end{array}$ & $\begin{array}{c}0.024 * * * \\
{[0.007]}\end{array}$ & $\begin{array}{c}0.131 * * * \\
{[0.005]}\end{array}$ & $\begin{array}{c}0.091 * * * \\
{[0.004]}\end{array}$ \\
\hline CFlow & $\begin{array}{c}0.046 * * * \\
{[0.003]}\end{array}$ & $\begin{array}{l}-0.005 \\
{[0.003]}\end{array}$ & $\begin{array}{c}0.338 * * * \\
{[0.005]}\end{array}$ & $\begin{array}{c}0.165 * * * \\
{[0.016]}\end{array}$ & $\begin{array}{c}0.177 * * * \\
{[0.018]}\end{array}$ & $\begin{array}{c}0.543 * * * \\
{[0.012]}\end{array}$ & $\begin{array}{c}0.069 * * * \\
{[0.002]}\end{array}$ & $\begin{array}{c}0.190 * * * \\
{[0.007]}\end{array}$ \\
\hline LnSize & $\begin{array}{c}0.003^{* * *} * \\
{[0.000]}\end{array}$ & $\begin{array}{c}0.014 * * * \\
{[0.000]}\end{array}$ & $\begin{array}{c}0.000 \\
{[0.000]}\end{array}$ & $\begin{array}{c}0.002 * * * \\
{[0.000]}\end{array}$ & $\begin{array}{c}0.001 * * * \\
{[0.000]}\end{array}$ & $\begin{array}{c}-0.001 * * * \\
{[0.000]}\end{array}$ & $\begin{array}{c}0.004 * * * \\
{[0.000]}\end{array}$ & $\begin{array}{c}0.000 * * \\
{[0.000]}\end{array}$ \\
\hline ChStdebt & $\begin{array}{c}-0.020 * * * \\
{[0.004]}\end{array}$ & $\begin{array}{c}-0.012 \\
{[0.008]}\end{array}$ & $\begin{array}{c}-0.021 * * * \\
{[0.005]}\end{array}$ & $\begin{array}{c}-0.059 * * * \\
{[0.006]}\end{array}$ & $\begin{array}{c}-0.026 * * * \\
{[0.007]}\end{array}$ & $\begin{array}{c}0.019 * * \\
{[0.010]}\end{array}$ & $\begin{array}{c}-0.021 * * * \\
{[0.004]}\end{array}$ & $\begin{array}{c}-0.021 * * * \\
{[0.005]}\end{array}$ \\
\hline$F D$ & $\begin{array}{c}0.000 \\
{[0.001]}\end{array}$ & $\begin{array}{c}-0.007 * * * \\
{[0.002]}\end{array}$ & $\begin{array}{c}0.005 * * * \\
{[0.001]}\end{array}$ & $\begin{array}{c}0.001 \\
{[0.001]}\end{array}$ & $\begin{array}{c}0.003 * * * \\
{[0.001]}\end{array}$ & $\begin{array}{c}0.008 * * * \\
{[0.001]}\end{array}$ & $\begin{array}{c}-0.001 \\
{[0.001]}\end{array}$ & $\begin{array}{c}0.004 * * * \\
{[0.001]}\end{array}$ \\
\hline$D_{c f l o w}$ & $\begin{array}{c}0.005 * * * \\
{[0.001]}\end{array}$ & & & & & & $\begin{array}{c}-0.066 * * * \\
{[0.002]}\end{array}$ & $\begin{array}{c}-0.058 * * * \\
{[0.002]}\end{array}$ \\
\hline Net_Issue ${ }^{*} D_{\text {cflow }}\left(\beta_{\mathrm{E}}\right)$ & $\begin{array}{c}-0.048 * * * \\
{[0.005]}\end{array}$ & & & & & & $\begin{array}{c}-0.049 * * * \\
{[0.005]}\end{array}$ & $\begin{array}{c}0.002 \\
{[0.007]}\end{array}$ \\
\hline Net_Debt* $D_{\text {cflow }}\left(\beta_{\mathrm{D}}\right)$ & $\begin{array}{c}-0.146 * * * \\
{[0.010]}\end{array}$ & & & & & & $\begin{array}{c}-0.139 * * * \\
{[0.008]}\end{array}$ & $\begin{array}{c}-0.086 * * * \\
{[0.008]}\end{array}$ \\
\hline Cflow $^{*} \boldsymbol{D}_{\text {cflow }}\left(\beta_{\mathrm{C}}\right)$ & $\begin{array}{c}0.305 * * * \\
{[0.006]}\end{array}$ & & & & & & $\begin{array}{c}0.528 * * * \\
{[0.013]}\end{array}$ & $\begin{array}{c}0.371 * * * \\
{[0.014]}\end{array}$ \\
\hline Adjusted R-sq & 0.274 & 0.316 & 0.25 & 0.133 & 0.137 & 0.263 & 0.273 & 0.256 \\
\hline \# Of Observations & 235069 & 62214 & 172855 & 57129 & 58082 & 57644 & 235069 & 172855 \\
\hline$F$ Test $\left(\beta_{\mathrm{E}}\right)+\left(\beta_{\mathrm{D}}\right)+\left(\beta_{\mathrm{C}}\right)=0$ & $75.0 * * *$ & & & & & & $475.0 * * *$ & $276.7 * * *$ \\
\hline$F$ Test $\left(\beta_{\mathrm{E}}\right)=\left(\beta_{\mathrm{D}}\right)$ & $84.3 * * *$ & & & & & & $84.6^{* * *}$ & $65.7 * * *$ \\
\hline$F$ Test $\left(\beta_{\mathrm{E}}\right)=\left(\beta_{\mathrm{C}}\right)$ & $2383 * * *$ & & & & & & $1574 * * *$ & $499 * * *$ \\
\hline$F$ Test $\left(\beta_{\mathrm{D}}\right)=\left(\beta_{\mathrm{C}}\right)$ & $1709 * * *$ & & & & & & $983 * * *$ & $406^{* * *}$ \\
\hline
\end{tabular}


Table 7: Decompositions of savings by characteristics

This table reports estimates of OLS regressions for the change in cash (ChCash) controlling for country, year and industry effects. Standard errors given in brackets are clustered at the firm level. Definitions of variables are given in Table 1 . The symbols ***,**, * denote statistical significance at the $1 \%, 5 \%$, and $10 \%$ levels, respectively.

\begin{tabular}{|c|c|c|c|c|c|c|c|c|}
\hline & \multicolumn{4}{|c|}{ Panel A: The role of financial constraints } & \multicolumn{4}{|c|}{ Panel B: The role of $R \& D$} \\
\hline & $\begin{array}{c}\text { Combined s } \\
\text { Young }\end{array}$ & $\begin{array}{l}\text { le of Small- } \\
\text { Big-Old }\end{array}$ & $\begin{array}{l}\text { Small and } \\
\text { Young }\end{array}$ & Big and Old & All Ol & rations & Pos RD & $\begin{array}{c}\text { Zero and } \\
\text { missing }\end{array}$ \\
\hline Constant & $-0.023^{*}$ & -0.015 & $-0.127 * * *$ & $-0.039 * * *$ & -0.014 & -0.01 & $-0.037 * * *$ & -0.01 \\
\hline \multirow[t]{2}{*}{ Net_Issue } & $0.309 * * *$ & $0.309 * * *$ & $0.344 * * *$ & $0.298 * * *$ & $0.328 * * *$ & $0.328 * * *$ & $0.423 * * *$ & $0.328 * * *$ \\
\hline & {$[0.024]$} & {$[0.024]$} & {$[0.006]$} & {$[0.024]$} & {$[0.003]$} & {$[0.003]$} & {$[0.004]$} & {$[0.003]$} \\
\hline \multirow{2}{*}{ Net_Debt } & $0.046 * * *$ & $0.038 * * *$ & $0.140 * * *$ & $0.084 * * *$ & $0.089 * * *$ & $0.082 * * *$ & $0.185 * * *$ & $0.070 * * *$ \\
\hline & {$[0.012]$} & {$[0.012]$} & {$[0.016]$} & {$[0.011]$} & {$[0.004]$} & [0.004] & [0.008] & {$[0.005]$} \\
\hline \multirow{2}{*}{ CFlow } & $0.147 * * *$ & $0.147 * * *$ & $0.075 * * *$ & $0.146^{* * *}$ & $0.087 * * *$ & $0.088 * * *$ & $0.163 * * *$ & $0.091 * * *$ \\
\hline & {$[0.010]$} & {$[0.010]$} & {$[0.006]$} & {$[0.010]$} & [0.002] & [0.002] & {$[0.003]$} & [0.002] \\
\hline \multirow[t]{2}{*}{ LnSize } & & & $0.022 * * *$ & $0.002 * * *$ & $0.002 * * *$ & $0.002 * * *$ & $0.004 * * *$ & $0.001 * * *$ \\
\hline & & & {$[0.001]$} & {$[0.000]$} & {$[0.000]$} & {$[0.000]$} & {$[0.000]$} & {$[0.000]$} \\
\hline \multirow[t]{2}{*}{ ChStdebt } & & $-0.048 * * *$ & -0.013 & $-0.111^{* * *}$ & & $-0.034 * * *$ & $-0.015^{*}$ & $-0.042 * * *$ \\
\hline & & {$[0.012]$} & {$[0.016]$} & [0.012] & & [0.004] & {$[0.008]$} & [0.005] \\
\hline$F D$ & & [0.002] & {$[0.003]$} & {$[0.001]$} & & {$[0.001]$} & {$[0.001]$} & {$[0.001]$} \\
\hline \multirow[t]{2}{*}{$V A R$} & $-0.008 * * *$ & $-0.008 * * *$ & & & $-0.012 * * *$ & $-0.012 * * *$ & & \\
\hline & [0.002] & [0.002] & & & {$[0.001]$} & [0.001] & & \\
\hline \multirow{2}{*}{ Net_Issue $* V A R\left(\beta_{\mathrm{E}}\right)$} & $0.051 * *$ & $0.051 * *$ & & & $0.092 * * *$ & $0.092 * * *$ & & \\
\hline & {$[0.025]$} & {$[0.025]$} & & & {$[0.005]$} & {$[0.005]$} & & \\
\hline \multirow{2}{*}{ Net_Debt*VAR $\left(\beta_{\mathrm{D}}\right)$} & $0.111 * * *$ & $0.110 * * *$ & & & $0.065^{* * *} *$ & $0.066^{* * *}$ & & \\
\hline & {$[0.012]$} & {$[0.012]$} & & & {$[0.005]$} & {$[0.005]$} & & \\
\hline \multirow[t]{2}{*}{ Cflow $* \operatorname{VAR}\left(\beta_{\mathrm{C}}\right)$} & $-0.029 * * *$ & $-0.027 * *$ & & & $0.081 * * *$ & $0.080 * * *$ & & \\
\hline & [0.011] & {$[0.011]$} & & & [0.004] & {$[0.004]$} & & \\
\hline Adjusted $R-s q$ & 0.275 & 0.276 & 0.295 & 0.129 & 0.259 & 0.259 & 0.306 & 0.224 \\
\hline \# Of Observations & 39648 & 39648 & 19913 & 19633 & 235069 & 235069 & 87348 & 147721 \\
\hline$F$ Test $\left(\beta_{\mathrm{E}}\right)+\left(\beta_{\mathrm{D}}\right)+\left(\beta_{\mathrm{C}}\right)=0$ & $18.7 * * *$ & $18.9 * * *$ & & & $699 * * *$ & $704 * * *$ & & \\
\hline$F$ Test $\left(\beta_{\mathrm{E}}\right)=\left(\beta_{\mathrm{D}}\right)$ & $4.94 * *$ & $4.58 * *$ & $143 * * *$ & $64.8^{* * *}$ & $13.6^{* * *}$ & $13.5^{* * *}$ & $713 * * *$ & $2054 * * *$ \\
\hline$F$ Test $\left(\beta_{\mathrm{E}}\right)=\left(\beta_{\mathrm{C}}\right)$ & $10.0 * * *$ & $9.68 * * *$ & $2123 * * *$ & $38.1 * * *$ & $6.02 * * *$ & $6.79 * * *$ & $4550 * * *$ & $4779 * * *$ \\
\hline
\end{tabular}




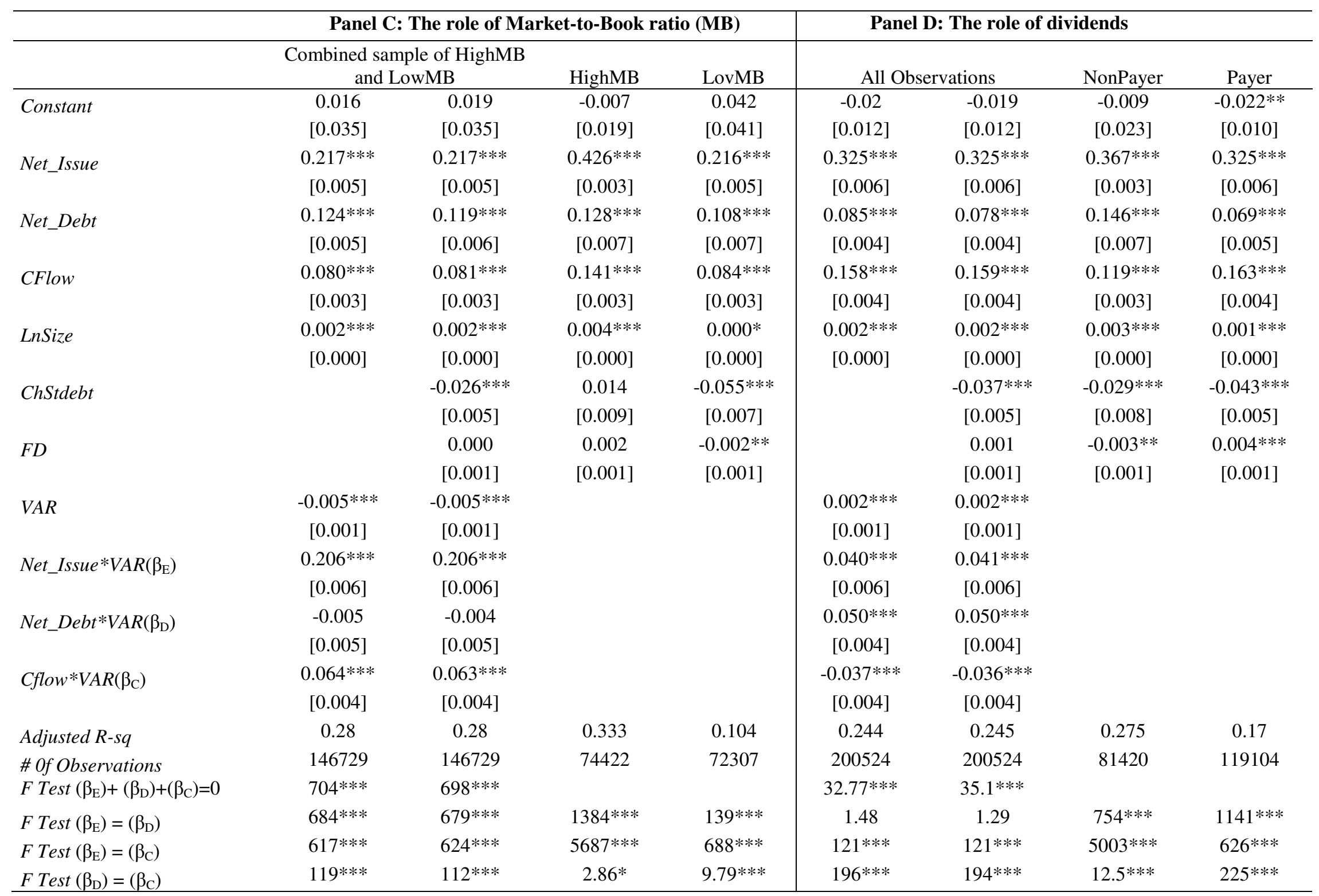




\begin{tabular}{|c|c|c|c|c|c|c|c|c|}
\hline & \multicolumn{4}{|c|}{ Panel E: The role of financial structure } & \multicolumn{4}{|c|}{ Panel F: The role of law system } \\
\hline & \multicolumn{2}{|c|}{ All Observations } & \multirow{2}{*}{$\begin{array}{c}\text { Bank } \\
-0.019 * * \\
{[0.009]}\end{array}$} & \multirow{2}{*}{$\begin{array}{c}\text { Market } \\
-0.023^{* *} \\
{[0.009]}\end{array}$} & \multicolumn{2}{|c|}{ All Observations } & \multirow{2}{*}{$\begin{array}{c}\text { Civil } \\
-0.004 \\
{[0.009]}\end{array}$} & \multirow{2}{*}{$\begin{array}{c}\text { Common } \\
-0.027 * * * \\
{[0.009]}\end{array}$} \\
\hline Constant & $-0.022 * *$ & $-0.023 * *$ & & & $-0.021 * *$ & $-0.022 * *$ & & \\
\hline \multirow{2}{*}{ Net_Issue } & $0.358 * * *$ & $0.358 * * *$ & $0.407 * * *$ & $0.359 * * *$ & $0.357 * * *$ & $0.358 * * *$ & $0.388 * * *$ & $0.358 * * *$ \\
\hline & {$[0.003]$} & {$[0.003]$} & {$[0.009]$} & {$[0.003]$} & {$[0.003]$} & {$[0.003]$} & {$[0.007]$} & {$[0.003]$} \\
\hline Net_Debt & $0.103 * * *$ & $0.096 * * *$ & $0.135 * * *$ & $0.095 * * *$ & $0.101 * * *$ & $0.095 * * *$ & $0.121 * * *$ & $0.095 * * *$ \\
\hline \multirow[t]{2}{*}{ CFlow } & $0.112 * * *$ & $0.113^{* * *}$ & $0.179 * * *$ & $0.112 * * *$ & $0.111 * * *$ & $0.112 * * *$ & $0.170 * * *$ & $0.109 * * *$ \\
\hline & {$[0.002]$} & {$[0.002]$} & {$[0.008]$} & {$[0.002]$} & {$[0.002]$} & {$[0.002]$} & {$[0.007]$} & {$[0.002]$} \\
\hline \multirow[t]{2}{*}{ LnSize } & $0.002 * * *$ & $0.002 * * *$ & 0.000 & $0.002 * * *$ & $0.002 * * *$ & $0.002 * * *$ & 0.000 & $0.003 * * *$ \\
\hline & {$[0.000]$} & {$[0.000]$} & {$[0.000]$} & {$[0.000]$} & {$[0.000]$} & {$[0.000]$} & {$[0.000]$} & {$[0.000]$} \\
\hline \multirow[t]{2}{*}{ ChStdebt } & & $-0.033 * * *$ & $-0.096 * * *$ & $-0.022 * * *$ & & $-0.033 * * *$ & $-0.112 * * *$ & -0.007 \\
\hline & & [0.004] & {$[0.008]$} & {$[0.005]$} & & [0.004] & [0.007] & {$[0.005]$} \\
\hline$F D$ & & 0.000 & 0.000 & 0.000 & & 0.000 & $0.003 * * *$ & $-0.002 * * *$ \\
\hline \multirow[t]{2}{*}{$V A R$} & $-0.017 * * *$ & $-0.017 * * *$ & & & $-0.014 * * *$ & $-0.015^{* * *}$ & & \\
\hline & [0.005] & [0.005] & & & {$[0.005]$} & {$[0.005]$} & & \\
\hline \multirow{2}{*}{$N e t \_I s s u e^{*} V A R\left(\beta_{\mathrm{E}}\right)$} & $0.051 * * *$ & $0.051 * * *$ & & & $0.032 * * *$ & $0.032 * * *$ & & \\
\hline & [0.009] & {$[0.009]$} & & & {$[0.008]$} & {$[0.008]$} & & \\
\hline \multirow[t]{2}{*}{$N e t \_D e b t * V A R\left(\beta_{\mathrm{D}}\right)$} & $0.028 * * *$ & $0.028 * * *$ & & & $0.026 * * *$ & $0.026 * * *$ & & \\
\hline & [0.007] & {$[0.007]$} & & & {$[0.006]$} & {$[0.006]$} & & \\
\hline \multirow{2}{*}{ Cflow $* \operatorname{VAR}\left(\beta_{\mathrm{C}}\right)$} & $0.063 * * *$ & $0.062 * * *$ & & & $0.055^{* * *}$ & $0.054 * * *$ & & \\
\hline & {$[0.008]$} & {$[0.008]$} & & & {$[0.007]$} & {$[0.007]$} & & \\
\hline Adjusted $R-s q$ & 0.253 & 0.253 & 0.263 & 0.252 & 0.253 & 0.253 & 0.26 & 0.253 \\
\hline \# Of Observations & 235037 & 235037 & 41818 & 193219 & 235037 & 235037 & 60538 & 174499 \\
\hline$F$ Test $\left(\beta_{\mathrm{E}}\right)+\left(\beta_{\mathrm{D}}\right)+\left(\beta_{\mathrm{C}}\right)=0$ & $98.6^{* * *}$ & $97.8 * * *$ & & & $83.5 * * *$ & $81.9 * * *$ & & \\
\hline$F \operatorname{Test}\left(\beta_{\mathrm{E}}\right)=\left(\beta_{\mathrm{D}}\right)$ & $4.02 * *$ & $3.88 * *$ & $463.4 * * *$ & $2595 * * *$ & 0.42 & 0.37 & $692 * * *$ & $2334 * * *$ \\
\hline$F$ Test $\left(\beta_{\mathrm{E}}\right)=\left(\beta_{\mathrm{C}}\right)$ & 1.01 & 0.98 & $396.1 * * *$ & $8605 * * *$ & $5.44 *$ & $5.32 *$ & $533 * * *$ & $8360 * * *$ \\
\hline
\end{tabular}




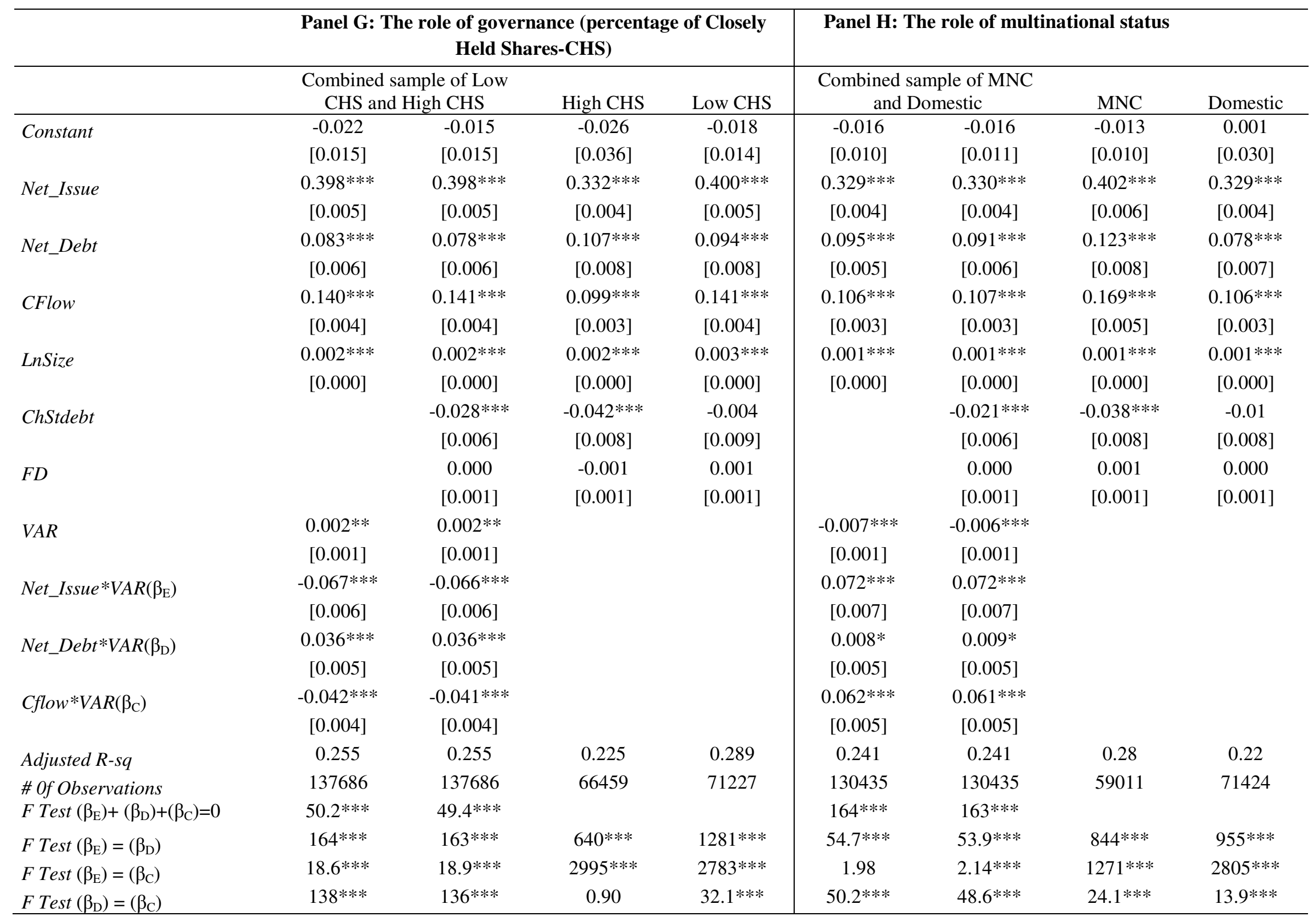




\section{Table 8: The relationship between financial constraints and characteristics}

This table reports estimates of OLS regressions for the change in cash (ChCash) controlling for country, year and industry effects. Standard errors given in brackets are clustered at the firm level. Definitions of variables are given in Table 1. The symbols $* * *, * *, *$ denote statistical significance at the $1 \%, 5 \%$, and $10 \%$ levels, respectively.

Panel A: Financially constraint firms (Small and young)

\begin{tabular}{|c|c|c|c|c|c|c|c|}
\hline & $\mathbf{R} \& \mathbf{D}$ & MB & Dividends & CHS & MNC & $\begin{array}{l}\text { Law } \\
\text { system }\end{array}$ & $\begin{array}{l}\text { Financial } \\
\text { structure }\end{array}$ \\
\hline \multirow[t]{2}{*}{ Constant } & $-0.140 * * *$ & $-0.094 * * *$ & $-0.143 * * *$ & $0.194 * * *$ & $0.249 * * *$ & $-0.125 * * *$ & $-0.126 * * *$ \\
\hline & {$[0.011]$} & [0.014] & [0.017] & [0.019] & [0.017] & [0.013] & [0.013] \\
\hline \multirow{2}{*}{ Net_Issue $\left(\beta_{\mathrm{E}}\right)$} & $0.305 * * *$ & $0.204 * * *$ & $0.342 * * *$ & $0.308 * * *$ & $0.320 * * *$ & $0.339 * * *$ & $0.341 * * *$ \\
\hline & [0.007] & {$[0.010]$} & {$[0.014]$} & {$[0.009]$} & {$[0.010]$} & {$[0.006]$} & {$[0.006]$} \\
\hline \multirow[t]{2}{*}{ Net_Debt $\left(\beta_{\mathrm{D}}\right)$} & $0.083 * * *$ & $0.095 * * *$ & -0.006 & $0.117 * * *$ & $0.112 * * *$ & $0.134 * * *$ & $0.135 * * *$ \\
\hline & {$[0.018]$} & {$[0.022]$} & {$[0.022]$} & [0.022] & {$[0.023]$} & {$[0.016]$} & {$[0.017]$} \\
\hline \multirow{2}{*}{ CFlow $\left(\beta_{\mathrm{C}}\right)$} & $0.048 * * *$ & $0.038 * * *$ & $0.113 * * *$ & $0.069 * * *$ & $0.075^{* * *}$ & $0.071 * * *$ & $0.072 * * *$ \\
\hline & {$[0.006]$} & {$[0.008]$} & {$[0.011]$} & {$[0.008]$} & [0.009] & {$[0.006]$} & [0.006] \\
\hline \multirow[t]{2}{*}{ LnSize } & $0.023 * * *$ & $0.016 * * *$ & $0.023 * * *$ & $0.022 * * *$ & $0.021 * * *$ & $0.022 * * *$ & $0.022 * * *$ \\
\hline & {$[0.001]$} & {$[0.002]$} & {$[0.001]$} & [0.002] & {$[0.002]$} & {$[0.001]$} & {$[0.001]$} \\
\hline \multirow{2}{*}{$V A R$} & $-0.032 * * *$ & $-0.015^{* * *}$ & 0.004 & $-0.018^{* * *}$ & $-0.013^{* * *}$ & $-0.369 * * *$ & $-0.358 * * *$ \\
\hline & {$[0.004]$} & {$[0.003]$} & {$[0.003]$} & [0.004] & {$[0.005]$} & [0.019] & {$[0.020]$} \\
\hline \multirow[t]{2}{*}{ Net_Issue*VAR $\left(\beta_{\mathrm{E}}\right)$} & $0.108 * * *$ & $0.229 * * *$ & -0.002 & $0.068 * * *$ & $0.079 * * *$ & $0.120 * * *$ & $0.105^{* * *}$ \\
\hline & [0.011] & {$[0.013]$} & {$[0.014]$} & {$[0.013]$} & {$[0.016]$} & {$[0.022]$} & {$[0.023]$} \\
\hline \multirow[t]{2}{*}{$N e t \_D e b t^{*} V A R\left(\beta_{\mathrm{D}}\right)$} & $0.142 * * *$ & $0.070 * * *$ & $0.130 * * *$ & $0.046^{*}$ & 0.045 & $0.088^{*}$ & $0.103 * *$ \\
\hline & {$[0.020]$} & [0.021] & {$[0.016]$} & [0.025] & {$[0.031]$} & {$[0.050]$} & {$[0.052]$} \\
\hline \multirow{2}{*}{ Cflow*VAR $\left(\beta_{\mathrm{C}}\right)$} & $0.080 * * *$ & $0.084 * * *$ & $-0.042 * * *$ & 0.015 & $0.047 * * *$ & $0.143^{* * *}$ & $0.116^{* * *}$ \\
\hline & {$[0.008]$} & [0.009] & [0.011] & [0.010] & [0.014] & {$[0.027]$} & {$[0.029]$} \\
\hline \multirow[t]{2}{*}{ ChStdebt } & -0.01 & -0.023 & -0.014 & 0.006 & 0.004 & -0.011 & -0.012 \\
\hline & {$[0.016]$} & {$[0.018]$} & [0.016] & {$[0.020]$} & {$[0.022]$} & {$[0.016]$} & {$[0.016]$} \\
\hline \multirow{2}{*}{$F D$} & -0.004 & $-0.007 *$ & -0.005 & -0.004 & -0.002 & $-0.007 * *$ & $-0.006^{*}$ \\
\hline & {$[0.003]$} & {$[0.004]$} & {$[0.003]$} & {$[0.005]$} & {$[0.005]$} & {$[0.003]$} & {$[0.003]$} \\
\hline Adjusted $R-s q$ & 0.305 & 0.318 & 0.3 & 0.282 & 0.287 & 0.296 & 0.296 \\
\hline \# Of Observations & 19913 & 14639 & 19889 & 12710 & 10385 & 19912 & 19912 \\
\hline$F$ Test $\left(\beta_{\mathrm{E}}\right)+\left(\beta_{\mathrm{D}}\right)+\left(\beta_{\mathrm{C}}\right)=0$ & $152^{* * *}$ & $195 * * *$ & $11.7^{* * *}$ & $14.8^{* * *}$ & $17.5^{* * *}$ & $33.9^{* * *}$ & $24.4^{* * *}$ \\
\hline$F$ Test $\left(\beta_{\mathrm{E}}\right)=\left(\beta_{\mathrm{D}}\right)$ & 2.09 & $40.6^{* * *}$ & $34.4 * * *$ & 0.64 & 0.93 & 0.35 & 0.00 \\
\hline$F$ Test $\left(\beta_{\mathrm{E}}\right)=\left(\beta_{\mathrm{C}}\right)$ & $6.77 * * *$ & $146^{* * *}$ & $7.26^{* * * *}$ & $17.3 * * *$ & $3.44^{*}$ & 0.38 & 0.08 \\
\hline$F \operatorname{Test}\left(\beta_{\mathrm{D}}\right)=\left(\beta_{\mathrm{C}}\right)$ & $8.90^{* * * *}$ & 0.35 & $81.4^{* * * *}$ & 1.35 & 0.01 & 1.01 & 0.05 \\
\hline
\end{tabular}


Panel B: Financially constraint firms (Big and old)

\begin{tabular}{|c|c|c|c|c|c|c|c|}
\hline & R\&D & MB & Dividends & CHS & MNC & $\begin{array}{c}\text { Law } \\
\text { system }\end{array}$ & $\begin{array}{l}\text { Financial } \\
\text { structure }\end{array}$ \\
\hline \multirow[t]{2}{*}{ Constant } & $-0.038 * * *$ & -0.009 & $-0.015^{* * * *}$ & $-0.047 * * *$ & 0.000 & $-0.038 * * *$ & $-0.037 * * *$ \\
\hline & [0.012] & {$[0.008]$} & [0.005] & [0.014] & {$[0.007]$} & [0.012] & [0.012] \\
\hline \multirow{2}{*}{ Net_Issue $\left(\beta_{\mathrm{E}}\right)$} & $0.275^{* * *}$ & $0.262 * * *$ & $0.307 * * *$ & $0.288 * * *$ & $0.205 * * *$ & $0.307 * * *$ & $0.294 * * *$ \\
\hline & [0.031] & [0.048] & [0.025] & [0.060] & [0.059] & [0.029] & [0.027] \\
\hline \multirow[t]{2}{*}{ Net_Debt $\left(\beta_{\mathrm{D}}\right)$} & $0.081 * * *$ & $0.088 * * *$ & $0.075^{* * *}$ & $0.090 * * *$ & $0.087 * * *$ & $0.072 * * *$ & $0.075^{* * *}$ \\
\hline & [0.011] & {$[0.014]$} & [0.011] & {$[0.015]$} & {$[0.016]$} & {$[0.012]$} & {$[0.011]$} \\
\hline \multirow{2}{*}{ CFlow $\left(\beta_{\mathrm{C}}\right)$} & $0.142 * * *$ & $0.129 * * *$ & $0.152 * * *$ & $0.173 * * *$ & $0.126 * * *$ & $0.142 * * *$ & $0.146^{* * *}$ \\
\hline & [0.013] & [0.017] & {$[0.011]$} & [0.024] & {$[0.020]$} & {$[0.012]$} & [0.011] \\
\hline \multirow{2}{*}{ LnSize } & $0.002 * * *$ & $0.003 * * *$ & $0.002 * * *$ & $0.002 * * *$ & 0.001 & $0.002 * * *$ & $0.002 * * *$ \\
\hline & {$[0.000]$} & [0.001] & {$[0.000]$} & {$[0.001]$} & {$[0.001]$} & {$[0.000]$} & {$[0.000]$} \\
\hline \multirow[t]{2}{*}{$V A R$} & -0.002 & -0.001 & 0.001 & 0.002 & -0.003 & -0.027 & -0.027 \\
\hline & {$[0.002]$} & {$[0.002]$} & {$[0.002]$} & {$[0.002]$} & {$[0.002]$} & [0.033] & {$[0.033]$} \\
\hline \multirow{2}{*}{ Net_Issue $* V A R\left(\beta_{\mathrm{E}}\right)$} & 0.063 & $0.109^{*}$ & -0.076 & 0.019 & $0.139^{* *}$ & -0.039 & 0.008 \\
\hline & [0.047] & {$[0.062]$} & {$[0.059]$} & [0.069] & {$[0.068]$} & {$[0.052]$} & {$[0.060]$} \\
\hline \multirow{2}{*}{$N e t \_D e b t^{*} V A R\left(\beta_{\mathrm{D}}\right)$} & 0.007 & -0.002 & $0.078 * * *$ & -0.01 & -0.004 & $0.042 * * *$ & $0.055^{* *}$ \\
\hline & {$[0.013]$} & {$[0.013]$} & {$[0.026]$} & {$[0.010]$} & {$[0.012]$} & {$[0.015]$} & {$[0.021]$} \\
\hline \multirow{2}{*}{ Cflow*VAR $\left(\beta_{\mathrm{C}}\right)$} & 0.012 & 0.023 & -0.017 & -0.031 & 0.031 & 0.015 & 0.002 \\
\hline & {$[0.019]$} & {$[0.021]$} & {$[0.026]$} & {$[0.027]$} & {$[0.025]$} & {$[0.021]$} & {$[0.023]$} \\
\hline \multirow{2}{*}{ ChStdebt } & $-0.112 * * *$ & $-0.110^{* * *}$ & $-0.114^{* * *}$ & $-0.115^{* * *}$ & $-0.087 * * *$ & $-0.112 * * *$ & $-0.113 * * *$ \\
\hline & [0.012] & {$[0.015]$} & [0.012] & {$[0.015]$} & {$[0.015]$} & {$[0.012]$} & {$[0.012]$} \\
\hline \multirow[t]{2}{*}{$F D$} & $0.005^{* * *}$ & $0.006 * * *$ & $0.005 * * *$ & $0.005^{* * *}$ & $0.006^{* * *}$ & $0.005 * * *$ & $0.005 * * *$ \\
\hline & [0.001] & [0.002] & {$[0.001]$} & {$[0.002]$} & {$[0.002]$} & {$[0.001]$} & {$[0.001]$} \\
\hline Adjusted R-sq & 0.13 & 0.133 & 0.132 & 0.128 & 0.12 & 0.13 & 0.13 \\
\hline \# Of Observations & 19633 & 10981 & 19607 & 11432 & 10739 & 19633 & 19633 \\
\hline$F$ Test $\left(\beta_{\mathrm{E}}\right)+\left(\beta_{\mathrm{D}}\right)+\left(\beta_{\mathrm{C}}\right)=0$ & 2.19 & $3.80 *$ & 0.04 & 0.08 & $5.14 * *$ & 0.09 & 0.84 \\
\hline$F$ Test $\left(\beta_{\mathrm{E}}\right)=\left(\beta_{\mathrm{D}}\right)$ & 1.28 & $3.02 *$ & $5.25 * *$ & 0.17 & $4.27 * *$ & 2.20 & 0.55 \\
\hline$F$ Test $\left(\beta_{\mathrm{E}}\right)=\left(\beta_{\mathrm{C}}\right)$ & 1.19 & 1.81 & 0.95 & 0.50 & 2.29 & 0.97 & 0.01 \\
\hline$F \operatorname{Test}\left(\beta_{\mathrm{D}}\right)=\left(\beta_{\mathrm{C}}\right)$ & 0.05 & 0.94 & $6.45^{* * * *}$ & 0.52 & 1.63 & 1.03 & $3.19 *$ \\
\hline
\end{tabular}


Table 9: The results excluding the US firms

This table reports estimates of OLS regressions on sample of countries other than the US for the change in cash (ChCash) controlling for country, year and industry effects. Standard errors given in brackets are clustered at the firm level. Definitions of variables are given in Table 1. The symbols $* * *, * *, *$ denote statistical significance at the $1 \%, 5 \%$, and $10 \%$ levels, respectively.

\begin{tabular}{|c|c|c|c|c|c|c|c|c|}
\hline & $\begin{array}{l}\text { Financial } \\
\text { constraint }\end{array}$ & R\&D & MB & Dividends & CHS & MNC & Law System & $\begin{array}{l}\text { Financial } \\
\text { structure }\end{array}$ \\
\hline Constant & $\begin{array}{c}-0.005 \\
{[0.004]}\end{array}$ & $\begin{array}{c}-0.009 \\
{[0.007]}\end{array}$ & $\begin{array}{c}0 \\
{[0.018]}\end{array}$ & $\begin{array}{c}-0.062 \\
{[0.056]}\end{array}$ & $\begin{array}{c}-0.025 * * * \\
{[0.007]}\end{array}$ & $\begin{array}{c}0.007 \\
{[0.013]}\end{array}$ & $\begin{array}{c}-0.009 \\
{[0.007]}\end{array}$ & $\begin{array}{c}-0.011 \\
{[0.007]}\end{array}$ \\
\hline Net_Issue $\left(\beta_{\mathrm{E}}\right)$ & $\begin{array}{c}0.260 * * * \\
{[0.024]}\end{array}$ & $\begin{array}{c}0.359 * * * \\
{[0.004]}\end{array}$ & $\begin{array}{c}0.271 * * * \\
{[0.009]}\end{array}$ & $\begin{array}{c}0.287 * * * \\
{[0.007]}\end{array}$ & $\begin{array}{c}0.381 * * * \\
{[0.006]}\end{array}$ & $\begin{array}{c}0.309 * * * \\
{[0.008]}\end{array}$ & $\begin{array}{c}0.375^{* * *} \\
{[0.004]}\end{array}$ & $\begin{array}{c}0.374 * * * \\
{[0.004]}\end{array}$ \\
\hline$N e t \_D e b t\left(\beta_{\mathrm{D}}\right)$ & $\begin{array}{c}0.068 * * * \\
{[0.012]}\end{array}$ & $\begin{array}{c}0.062 * * * \\
{[0.005]}\end{array}$ & $\begin{array}{c}0.079 * * * \\
{[0.006]}\end{array}$ & $\begin{array}{c}0.070 * * * \\
{[0.005]}\end{array}$ & $\begin{array}{c}0.080 * * * \\
{[0.006]}\end{array}$ & $\begin{array}{c}0.063 * * * \\
{[0.006]}\end{array}$ & $\begin{array}{c}0.052 * * * \\
{[0.005]}\end{array}$ & $\begin{array}{c}0.056 * * * \\
{[0.005]}\end{array}$ \\
\hline CFlow $\left(\beta_{\mathrm{C}}\right)$ & $\begin{array}{c}0.153 * * * \\
{[0.011]}\end{array}$ & $\begin{array}{c}0.150 * * * \\
{[0.003]}\end{array}$ & $\begin{array}{c}0.160 * * * \\
{[0.005]}\end{array}$ & $\begin{array}{c}0.179 * * * \\
{[0.004]}\end{array}$ & $\begin{array}{c}0.179 * * * \\
{[0.005]}\end{array}$ & $\begin{array}{c}0.147 * * * \\
{[0.006]}\end{array}$ & $\begin{array}{c}0.160 * * * \\
{[0.003]}\end{array}$ & $\begin{array}{c}0.165^{* * *} * \\
{[0.003]}\end{array}$ \\
\hline LnSize & & $\begin{array}{c}0.001 * * * \\
{[0.000]}\end{array}$ & $\begin{array}{c}0.001 * * * \\
{[0.000]}\end{array}$ & $\begin{array}{c}0.001 * * * \\
{[0.000]}\end{array}$ & $\begin{array}{c}0.001 * * * \\
{[0.000]}\end{array}$ & $\begin{array}{c}0 \\
{[0.000]}\end{array}$ & $\begin{array}{c}0.001 * * * \\
{[0.000]}\end{array}$ & $\begin{array}{c}0.001 * * * \\
{[0.000]}\end{array}$ \\
\hline$V A R$ & $\begin{array}{c}-0.011 * * * \\
{[0.002]}\end{array}$ & $\begin{array}{c}-0.009 * * * \\
{[0.001]}\end{array}$ & $\begin{array}{c}-0.005 * * * \\
{[0.001]}\end{array}$ & $\begin{array}{c}0.000 \\
{[0.001]}\end{array}$ & $\begin{array}{c}0.001 * \\
{[0.001]}\end{array}$ & $\begin{array}{c}-0.005 * * * \\
{[0.001]}\end{array}$ & $\begin{array}{c}-0.012 * * * \\
{[0.004]}\end{array}$ & $\begin{array}{c}-0.013 * * * \\
{[0.004]}\end{array}$ \\
\hline Net_Issue $* V A R\left(\beta_{\mathrm{E}}\right)$ & $\begin{array}{c}0.170 * * * \\
{[0.025]}\end{array}$ & $\begin{array}{c}0.082 * * * \\
{[0.008]}\end{array}$ & $\begin{array}{c}0.153 * * * \\
{[0.010]}\end{array}$ & $\begin{array}{c}0.126^{* * *} * \\
{[0.009]}\end{array}$ & $\begin{array}{c}0.003 \\
{[0.009]}\end{array}$ & $\begin{array}{c}0.076^{* * *} \\
{[0.010]}\end{array}$ & $\begin{array}{c}0.008 \\
{[0.008]}\end{array}$ & $\begin{array}{c}0.034 * * * \\
{[0.010]}\end{array}$ \\
\hline$N e t \_D e b t^{*} V A R\left(\beta_{\mathrm{D}}\right)$ & $\begin{array}{c}0.021 \\
{[0.014]}\end{array}$ & $\begin{array}{c}0.022 * * * \\
{[0.007]}\end{array}$ & $\begin{array}{c}-0.014 * * \\
{[0.006]}\end{array}$ & $\begin{array}{c}0.018 * * * \\
{[0.007]}\end{array}$ & $\begin{array}{c}-0.023 * * * \\
{[0.006]}\end{array}$ & $\begin{array}{c}0.001 \\
{[0.006]}\end{array}$ & $\begin{array}{c}0.039 * * * \\
{[0.005]}\end{array}$ & $\begin{array}{c}0.044 * * * \\
{[0.006]}\end{array}$ \\
\hline Cflow $* V A R\left(\beta_{\mathrm{C}}\right)$ & $\begin{array}{c}0.046^{* * *} \\
{[0.013]}\end{array}$ & $\begin{array}{c}0.078 * * * \\
{[0.006]}\end{array}$ & $\begin{array}{c}0.019 * * * \\
{[0.006]}\end{array}$ & $\begin{array}{c}0.010 * \\
{[0.006]}\end{array}$ & $\begin{array}{c}-0.018 * * * \\
{[0.007]}\end{array}$ & $\begin{array}{c}0.049 * * * \\
{[0.007]}\end{array}$ & $\begin{array}{c}0.038 * * * \\
{[0.006]}\end{array}$ & $\begin{array}{c}0.031 * * * \\
{[0.007]}\end{array}$ \\
\hline ChStdebt & $\begin{array}{c}-0.045^{* * *} \\
{[0.011]}\end{array}$ & $\begin{array}{c}-0.042 * * * \\
{[0.004]}\end{array}$ & $\begin{array}{c}-0.037 * * * \\
{[0.005]}\end{array}$ & $\begin{array}{c}-0.047 * * * \\
{[0.005]}\end{array}$ & $\begin{array}{c}-0.035 * * * \\
{[0.006]}\end{array}$ & $\begin{array}{c}-0.034 * * * \\
{[0.006]}\end{array}$ & $\begin{array}{c}-0.042 * * * \\
{[0.004]}\end{array}$ & $\begin{array}{c}-0.042 * * * \\
{[0.004]}\end{array}$ \\
\hline$F D$ & $\begin{array}{c}0.001 \\
{[0.001]}\end{array}$ & $\begin{array}{c}0.001 * * * \\
{[0.001]}\end{array}$ & $\begin{array}{c}0.002 * * * \\
{[0.001]}\end{array}$ & $\begin{array}{c}0.001 * * \\
{[0.001]}\end{array}$ & $\begin{array}{l}0.002 * * \\
{[0.001]}\end{array}$ & $\begin{array}{l}0.001 * * \\
{[0.001]}\end{array}$ & $\begin{array}{c}0.001 * * \\
{[0.001]}\end{array}$ & $\begin{array}{l}0.001 * * \\
{[0.001]}\end{array}$ \\
\hline Adjusted R-sq & 0.292 & 0.244 & 0.263 & 0.233 & 0.24 & 0.218 & 0.241 & 0.241 \\
\hline \# Of Observations & 26315 & 137263 & 87377 & 116393 & 79298 & 70031 & 137231 & 137231 \\
\hline $\begin{array}{l}F \text { Test }\left(\beta_{\mathrm{E}}\right)+\left(\beta_{\mathrm{D}}\right)+\left(\beta_{\mathrm{C}}\right)=0 \\
F \text { Test }\left(\beta_{\mathrm{E}}\right)=\left(\beta_{\mathrm{D}}\right)\end{array}$ & $\begin{array}{l}56.4 * * * \\
26.8 * * *\end{array}$ & $\begin{array}{l}222 * * * \\
31.6 * * *\end{array}$ & $\begin{array}{l}129 * * * \\
190 * * *\end{array}$ & $\begin{array}{l}155^{* * *} \\
94.1 * * *\end{array}$ & $\begin{array}{l}8.35 * * * \\
5.56 * *\end{array}$ & $\begin{array}{l}78.4 * * * \\
38.2 * * *\end{array}$ & $\begin{array}{l}54.8 * * * \\
9.51 * * *\end{array}$ & $\begin{array}{c}66.5 * * * \\
0.75\end{array}$ \\
\hline$F$ Test $\left(\beta_{\mathrm{E}}\right)=\left(\beta_{\mathrm{C}}\right)$ & $21,2 * * *$ & 0.18 & $141 * * *$ & $126^{* * *}$ & $4.32 * *$ & $4.97 * *$ & $9.13 * * *$ & 0.06 \\
\hline$F$ Test $\left(\beta_{\mathrm{D}}\right)=\left(\beta_{\mathrm{C}}\right)$ & 1.64 & $39.5 * * *$ & $13.6^{* * *}$ & 0.66 & 0.36 & $23.5^{* * *}$ & 0.02 & 1.90 \\
\hline
\end{tabular}

